\title{
Ser Parte e Ter Parte: Servidão e Iiberdade na Ética IV
}

(Prefácio, definições, axioma)

\author{
Marilena Chauí*
}

Resumo: Este artigo procura analisar o Livro IV da Ética, mostrando como Espinosa, ao pensar as noções de liberdade e servidão humana, escapa às críticas que buscam encontrar em sua filosofia uma contradição entre a idéia de uma natureza absolutamente necessária ("fatalismo") e sua pretensão de afimar a liberdade do sábio.

Palavras-chave: finitude - necessidade - liberdade - servidão

A Gérard Lebrun que, em 1976 e agora, inspirou este estudo

\section{Finitude e Fortuna}

A tradição interpretativa da filosofia espinosana foi marcada pela condenação cristã do ateísmo de Espinosa. No século XVII, a crítica dirigiase sobretudo ao Deus espinosano ("sem intelecto e sem vontade") ou àquilo que o século indicava com o termo "fatalismo". Em nossos dias, a crítica, agora sob o signo da filosofia kantiana, dirige-se preferencialmente ao 
homem espinosano (incapaz de liberdade) ou àquilo que se costuma significar com a noção de "determinismo". Nas inúmeras versões desta crítica - de Velthuysen e Leibniz, passando por Kant e Jacobi, até Cohen e Kolakowski - afimou-se a incoerência do pensamento espinosano, internamente minado por cuas pretensões inconciliáveis: a afimação da necessidade absoluta, que rege o curso causal da Natureza, e a dedução da liberdade plena do sábio, no seio da Natureza. A tradição propôs, assim, "o problema do espinosismo" como contradição (tanto em Deus como no homem) entre necessidade e liberdade.

Durante os últimos três séculos, os estudiosos da filosofia de Espinosa refutaram a crítica e solucionaram o "problema". Todavia, ocupando-se predominantemente com este último, muitos acabaram perdendo de vista dois aspectos fundamentais da obra de Espinosa. Em primeiro lugar, que o "problema do espinosismo" já havia sido desfeito e criticado pelo próprio Espinosa, quando demonstrara a diferença entre as imagens da necessidade e da liberdade e suas idéias verdadeiras, ou, em outras palavras, quando demonstrara que o "problema" só existe no interior do imaginário teológicometafísico, no qual são identificadas necessidade e onipotência (no caso de Deus), liberdade e vontade (no caso do homem) . Em segundo lugar, e como consequiência, perderam de vista a dificuldade real proposta pela filosofia espinosana, no tocante ao homem, qual seja, a relação entre liberdade e fortuna. Embrenhando-se no falso problema da necessidade, esqueceramse de que o verdadeiro problema encontrava-se no pólo oposto, isto é, na contingência. É esta a questão desenvolvida pelo Livro IV da Ética.

Nos Livros II e III, Espinosa demonstra que o homem é um ser finito ("a substância não pertence ao ser do homem"), retirando as consequiências necessárias da finitude: idéias inadequadas, no conhecimento, causas inadequadas, na ação, paixões, na vida ético-psíquica ${ }^{(1)}$. No quarto Livro, porém, a finitude humana é levada ao limite. A servidão não é uma inadequação qualquer. É a maneira total de ser e existir, viver e pensar sob a forma da impotência, da exterioridade e da ilusão de onipotência que obscurece nossa fraqueza real. Aqui, idéias que os livros anteriores haviam deduzido parte da Natureza, negação, privação, contrariedade - são retomadas noutro registro para o qual somos alertados logo nas definições que abrem a parte
IV, onde reaparecem, na qualidade de conceitos, imagens que, anteriormente, haviam sido despojadas de significado metafísico: as do possível e do contingente. Com elas, somos lançados da ordem necessária à ordem comum da Natureza, onde reina soberana a Fortuna.

A finitude, agora, já não é a da parte finita da Natureza como efeito e consequiência da atividade dos atributos e modos infinitos de Deus, mas a da parte separada do todo, isolada, indefesa, arrastada em direções contrárias, "vendo o melhor, porém seguindo o pior" para si. Aqui, qualquer coisa pode ser por acidente causa ou efeito de qualquer outra. Aqui, cada parte da Natureza encontrará sempre outras mais fortes e mais poderosas do que ela e a ela contrárias, capazes de destruí-la.

Servidão é a maneira de ser quando estamos literalmente possuídos pela exterioridade contingente cujo nome a filosofia jamais cessou de pronunciar: a caprichosa Fortuna. O problema é grave, pois como uma filosofia da necessidade absoluta poderia dar lugar à Fortuna? Como a liberdade, que é uma idéia evidente sob o ponto de vista da necessidade, há de ser possível sob o império da Fortuna? Desta perspectiva, Espinosa é um clássico, pois a questão clássica sempre foi: como distinguir o que está sob nosso poder e o que está sob o poderio da Fortuna? Noutra perspectiva, porém, o surgimento da Fortuna parece destruir a cadeia dedutiva do more geometrico, uma vez que pressupõe aquilo que o Livro I havia destruído, ou seja, a imagem de uma vontade cósmica onipotente e insondável. Metafisicamente, a Fortuna é impossível. Eticamente, porém, é inarredável. Mais do que isto. É justamente sua falta de realidade metafísica e sua plena realidade ética que oferece o fio condutor para seguimos o Livro IV: o sujeito (rigorosamente como subjectum e como objectum) do quarto livro da Ética é o modo finito humano na curação, quando experimenta e vive sua própria finitude cercado por forças superiores às suas e que ele imagina dominar e controlar, sem se dar conta de que está sendo arrastado por elas. Eis por que, sem possuir densidade metafísica (não existe do ponto de vista do infinitamente infinito), a Fortuna possui peso metafísico no campo ético (existe do ponto de vista da experiência da finitude) .

Três proposições e um capítulo do Livro IV expõem a presença inelutável da Fortuna e o laço que a prende à finitude humana: a proposição 1 
("nada do que uma idéia falsa possui de positivo é destruído pelo verdadeiro enquanto verdadeiro"), a proposição 4 ("é impossível que o homem não seja uma parte da Natureza e não possa sofrer outras mudanças que não aquelas que podem ser compreendidas apenas por sua natureza e das quais é causa adequada") , a proposição 15 ("o desejo que nasce do verdadeiro conhecimento do bem e do mal pode ser extinto ou refreado por muitos outros desejos que nascem de outros afetos que nos dominam") e o capítulo 32 ("Mas a potência humana é muito limitada e é infinitamente ultrapassada pela potência das causas exteriores; por conseguinte, não temos poder absoluto de adaptar ao nosso uso as coisas que estão fora de nós. Todavia, quanto às coisas que nos acontecem contra o que pode a lei de nossa utilidade, suporta-las-emos com ânimo igual, se tivermos consciência de termos cumprido nossa função, de que a potência que temos não podia ir até o ponto de nos permitir evitá-las; e de que somos uma parte da Natureza, cuja ordem seguimos") .

Espinosa nos propõe um oxímoro: a Fortuna é necessária. A lógica dos afetos opera em seu interior e a geometria deduz o mundo humano como campo de forças contrárias em luta, exigindo que indaguemos quais nos são favoráveis, quais desfavoráveis, quais duradouras, quais efêmeras, quais concordes com a razão, quais opostas a ela. A pergunta do Livro IV é explícita: como poderemos "passar de uma perfeição menor a outra, maior", isto é, sem deixarmos de ser finitos e sem abandonarmos a ordem comum da Natureza? A resposta espinosana - a liberdade racional é uma conquista contra a Fortuna no próprio campo da Fortuna - é obtida num percurso extremamente complexo que dá ao Livro IV um aspecto bastante diferente dos anteriores. Nestes, a cadeia dedutiva opera em sequiências contínuas; ao contrário, na quarta parte, há um vaivém incessante entre paixão e ação, imaginação e razão, ação e paixão, razão e imaginação. É inevitável que assim seja, pois a servidão faz aparecer a finitude lançada na contingência e, a cada passo, a tarefa da razão consistirá em pesar e avaliar a força dos afetos e a sua própria, comparada à deles, porque sem isto não poderá encontrar um caminho para passar da paixão à ação sem abandonar os afetos. A ordem comum da Natureza - a Fortuna - e a ordem necessária da Nature- za - a liberdade - não cessam de cruzar-se, chamar-se reciprocamente, marcar a força e a fraqueza da paixão, a fraqueza e a força da razão.

Numa prodigiosa reviravolta da tradição ético-metafísica, a filosofia espinosana demonstra que somos livres não apesar da necessidade, mas graças a ela e, ao contrário, que somos livres não graças à Fortuna, mas apesar dela. Expondo a vulnerabilidade extrema dos seres humanos e encontrando neles uma força peculiar que não pretende dominar nem controlar a Fortuna, mas venoê-la, expondo-a como fraqueza, ignorância e tristeza, a geometria da servidão deduz a virtude não como poderio intelectual sobre os afetos, mas como afeto mais forte do que as paixões, desnudandoas como naturais, necessárias, delírios e ilusões. Não por acaso, nos faz descobrir que a paixão mais submissa à Fortuna é justamente aquela que mais parece ser-lhe insubmissa:

"Essa imaginação, enquanto se aplica ao homem que tem de si mesmo uma opinião mais favorável do que seria justo, chama-se soberba (superbia), e é uma espécie de delírio, pois o homem que, de olhos abertos, sonha que pode fazer tudo o que alcança apenas com a imaginação, considera-o real e exalta-se com isto; não sendo capaz de imaginar algo que exclua a existência disso, limita sua própria potência de agir." (Espinosa 6, E III, 26e)

O Livro IV opera como conclusão extrema da dedução das paixões - a servidão - e como primeiro movimento da causa adequada rumo à liberdade racional, deduzida das noções comuns de bom, mau e natureza humana. É, assim, conclusão e começo, mediação indispensável entre os dois pontos limites da experiência humana: a passividade servil e a livre atividade do sábio. Nele, é central a idéia de pars Naturae, pois esta se realiza sob três formas: como inadequação extrema (a parte infinitamente menos potente do que a potência das causas externas, lançada sob a fortunae potestas), como adequação racional (a parte não mais isolada, mas articulada ao sistema interno de relações necessárias com outras partes do todo com as quais possui propriedades comuns, cada parte auxiliando a potência das outras 
porque são convenientes entre si) e como adequação intelectual ou reflexão (quando a parte experimenta a si mesma como essência singular eterna que toma parte na atividade infinita da qual é parte) .

Servidão ou impotência (natural e necessária) diante da Fortuna significa a parte humana isolada de toolas as outras, em luta com elas e contra elas, dominada por elas, sob os efeitos dos encontros contingentes entre partes isoladas na ordem comum da Natureza - estamos diante da pars partialis et contraria. Iiberdade racional significa a parte humana participando de uma estrutura de relações necessárias recíprocas entre partes dotadas de propriedades comuns que existem igualmente em cada uma delas e no todo - estamos diante da pars communis et conveniens. Liberdade ética significa a parte humana como causa adequada e formal de suas idéias e ações, causa eficiente imanente de seu pensar e agir, tomando parte na atividade infinita da qual é parte - estamos diante da pars singularis et imanens.

Passar da fortunae potestas ao amor intellectualis Dei, passar da condição extrínseca do "ser parte" à condição intrínseca do "tomar parte" é o movimento que conduz da servidão à liberdade.

Neste movimento, o instante crucial - verdadeira ruptura ética - é o da dedução da gênese necessária da passividade como determinação da potência do conatus pela potência das causas exteriores, quando a exterioridade entre as potências das coisas e a do indivíduo conpo-mente institui um campo de forças afetivas onde a servidão geminará e desdobrará seus efeitos. Porém, é neste mesmo movimento que a parte humana da Natureza, experimentando o risco de desaparição sob o poderio da Fortuna, descobre o que está em seu próprio poder ao conhecer-se como parte de um todo ou de uma comunidade de partes dotadas das mesmas propriedades. Essa queda extrema e essa descoberta crucial constituem o núcleo do Livro IV - servidão no isolamento e virtude no cidadão.

\section{O Prefácio}

"Chamo servidão (servitutem voco) a impotência humana (humanam impotentiam) para moderar e refrear os afetos (in moderandis et coercendis). Com efeito, o homem submetido (obnoxius) aos afetos não é senhor de si (sui juris), mas está sob o poderio da fortuna (fortunae potestate), de tal maneira que, freqüientemente, embora veja o que é melhor para si, vê-se coagido (coactus sit) a seguir o pior. Nesta parte, propus-me demonstrar a causa disto e o que há de bom e mau nos afetos."

A servidão é definida por um negativo: impotência humana (humanam impotentiam) para impor medida (moderandis) e freio (coercendis) aos afetos. Em lugar de submetê-los, o homem está submetido (obnoxius) a eles. Essa impotência tem como contrapartida um poderio que o domina, a Fortuna (fortunae potestate), contingência desagregadora, pois, como no verso de Ovídio, "vejo o melhor e o aprovo, mas sigo o pior".

Aparentemente, a definição espinosana é pouco inovadora, fazendo lembrar o estoicismo(2) . No entanto, a diferença face aos estóicos é significativa (como veremos adiante), bastando, no momento, observar que Espinosa não diz que os afetos são maus, mas, pelo contrário, pretende investigar o que há de bom e mau neles.

A definição espinosana é rigorosa e primorosamente jurídica, operando com as expressões sui juris, obnoxius, moderandis, coercendis e coactus sit, cuja articulação decorre do embate entre impotentia humana e fortunae potestas. Porque a definição nominal da servidão se realiza no campo jurídico, não será casual, mas necessário, que, ao final do Livro IV, quando a definição genética houver sido deduzida, Espinosa introduza os elementos da teoria do direito natural e do direito civil.

Impotência humana, a servidão é perda da potência de agir e de pensar do conatus corpo-mente. Em que se manifesta ela? Na incapacidade humana para dominar os afetos, impondo-lhes medida e freio. Assim, não é a mera existência dos afetos, como julgaria um estóico, que faz existir a 
servidão, mas a maneira pela qual o conatus se relaciona com eles. Os afetos, mesmo os passivos, não são doença do ânimo, ausência de razão sob os efeitos de falsas opiniões sobre o bem e o mal, vícios contra-natureza, perversão do apetite natural, perturbação da ordem da Natureza. São a maneira pela qual a mente afirma - imaginariamente e inadequadamente, na paixão, reflexivamente e adequadamente, na ação - a existência atual de seu corpo e as idéias dessa afirmação, tanto na ordem comum da Natureza quando na ordem necessária da Natureza. São a experiência psíquica das múltiplas afecções do corpo próprio, quando afetado pelos demais corpos ou afetando-os de variadas maneiras, e a manifestação dessa multiplicidade em idéias da mente. A vida afetiva é a maneira pela qual a mente interpreta a vida de seu corpo e sua própria vida, inadequada ou adequadamente.

Ora, sendo a servidão impotência, nela a mente interpreta seu corpo e a si mesma ou afirma a existência atual de seu corpo de maneira extremamente confusa e inadequada, inadequação que se oferece nas expressões: não ser ou não estar sui juris e estar obnoxius fortunae potestate. Năo ser ou não estar sui juris é ser causa inadequada (o efeito não pode ser deduzido ou conhecido pela natureza de sua causa) e ser passivo (o efeito ocorre em nós pela potência de algo exterior, de sorte que somos causa parcial dele) e, portanto, é estar submetido ao poderio da Fortuna, poderio externo marcado pela contingência, acidentalidade e arbitrariedade. Fis por que, tendo os livros anteriores, notadamente o Livro I, afastado qualquer dimensão metafísica do contingente e do possível, veremos estas noções ressurgirem no quarto Livro como objetos de definição e integrantes das demonstrações. A definição espinosana da servidão traduz os conceitos metafísicos de causa inadequada, causa adequada, atividade, passividade para a linguagem do direito: não ser ou não estar sob seu próprio direito (sui juris) é estar submetido (obnoxius) ao direito ou poder (potestas) de um outro. Essa tradução possui uma causa precisa: a servidão transcorre no campo intersubjetivo mediado pelas coisas.

O Direito Romano que o século XVII conhece é aquele que já sedimentou três transformações conceituais que o separam da origem propriamente romana (cf. Tuck 26 e Nicholas 18). Em primeiro lugar, aquela que identificou jus e dominium, de sorte que jus é o controle absoluto que o sujeito de direito exerce sobre as coisas conporais e incorporais que constituem seu mundo (vita, membra, res conporales, fama, honor, libertas); em segundo lugar, aquela pela qual o homem, enquanto sujeito de direito, tem poder absoluto sobre tudo quanto em seu mundo the permita conservar o que é de seu direito; em terceiro lugar, aquela que considera a liberdade uma faculdade do sujeito de direito e um dominium, de modo que ser sui juris é ser dominus de seu corpo, seus bens e sua liberdade. Porque esta última é facultas e dominiumpode ser retirada do sujeito, seja por transferência voluntária a um outro, seja por transferência forçada ou violenta a um outro. Nos dois casos, o sujeito, seja por servidão voluntária, seja por escravidão, toma-se alienus juris. No centro dessa concepção do jus encontram-se três faculttates: a vontade, a liberdade e a propriedade. A servidão define-se como perda de jus e dominium sobre o corpo, os bens, o mundo circundante e a liberdade (com ela, a fama e a honra). A servidão, tal como Espinosa a define, não enuncia, portanto, um juízo de valor sobre as paixões, mas descreve, de facto e de jure, a situação de quem perdeu poder e controle sobre si e sobre seu mundo.

Não estando sui juris, sob qual poder encontra-se o homem impotente para moderar e coibir seus afetos? Encontra-se obnoxius affectibus. Obnoxius (submetido a, exposto a) é um termo jurídico associado a dois pares de termos de onde deriva: noxa/noxius e nex/nexus. Noxa: falta, dano, crime; noxia: culpa, castigo, delito; noxius: culpado, criminoso, danoso; nex: assassinato, morte violenta; nexus: contrato que abriga o devedor ao credor, de quem fica escravo até a expiação da culpa ou pagamento da dívida. Obnoxius: sujeito a pena ou castigo, culpado, exposto ao poderio externo que o inclina independentemente de sua vontade; literalmente, arrastado por outro. Obnoxius está referido a uma dominação violenta cuja causa é uma violência anterior cometida por quem, agora, está submetido a um outro poder. Significando "estar exposto a", obnoxius indica uma submissão que deixa o submetido à mercê de um poder externo que o lança na direção que lhe aprouver. Donde a expressão de Tácito: obnoxius fortunae, reescrita por Espinosa como obnoxius affecturm viribus.

A servidão é impotência humana de quem, não estando sob seu próprio poder e direito, está sob o domínio de uma força impetuosa e violenta, 
exposto e arrastado por ela: a força dos afetos, affecturm viribus. Ora, quem não está sui juris é causa inadequada ou parcial do que se passa em seu interior e do que realiza externamente. Passiva, a servidão reencontra a distinção clássica dos discursos éticos entre o que está em nosso poder e o que não está em nosso poder. Assim, obnoxius affectibus significa: fortunae potestate. Na servidão, a potentia do conatus encontra-se sob a potestas da fortuna. Passividade, exterioridade, heteronomia são os termos éticos para o que nos foi apresentado em termos jurídicos, traduzindo termos metafísicos. Essa apresentação jurídica da servidão dbedece a um preceito espinosano que será enunciado logo a seguir (e que já fora enunciado nos Cogitata) : para saber o que uma palavra quer dizer é preciso ir, antes de tudo, à sua prima significatio e a primeira significação de servidão é jurídica.

Temos o quadro inicial da servidão humana. Aquele que, por impotência, deixa de estar sui juris para ficar sob o poderio de uma outra força, experimenta quatro situaçães simultâneas: a da alienação (está al lienus juris, ou, como prefere Espinosa, alterius juris); a da contrariedade (vendo o melhor, sente-se coagido a fazer o pior para si) ; a da violência (estando sob a força dos afetos, é arrastado ao pior pela incerta e caprichosa Fortuna) ; e a da fraqueza (perda de direitos e poderes, sujeição). A servidão é um embate de forças no qual a potência das coisas exteriores é superior à do conatus corpo-mente. Definida nominalmente, é preciso agora defini-la geneticamente ou, como escreve Espinosa, "determinar suas causas".

No entanto, o Prefácio parece sofrer uma intermupção, Espinosa introduzindo uma longa digressão sobre perfeito e imperfeito:

"Quem decidiu fazer alguma coisa e a perfez, dirá que sua obra está perfeita; e não só esse, mas também todo aquele que tiver conhecido exatamente a intenção e o escopo do autor (auctoris) de tal obra ou crê conhecê-los. Por exemplo, se alguém vir uma dora (que suponho não estar acabada) e souber que o escopo do autor da referida obra é edificar uma casa, dirá que a casa está imperfeita; pelo contrário, dirá que está perfeita quando vir que a obra chegou ao fim que lhe propusera o autor. Mas se alguém vê uma obra, não tendo nunca visto outra semelhante nem conhecido a intenção do artífice, não poderá saber se a dbra está perfeita ou imperfeita. Tal parece ter sido a primeira significação (prima significatio) destes vocábulos."

A internupção, porém, é aparente. A continuidade é dada pela presença da figura do auctor, historicamente articulada a duas outras na tradição jurídica: ao sujeito sui juris e ao poder de moderare.

Moderare (e também moderor) pertence ao vocabulário técnico e jurídico através de sua derivação de modus, uma medida que não é própria das coisas, mas imposta a elas por um senhor ou mestre que refletiu, deliberou e decidiu. A medida não é mensuração, mas moderação, "medida aplicada a quem ou ao que ignora toda medida" (Benvéniste 1, v. 2, p. 129), uma limitação ou um constrangimento (no texto de Espinosa, moderandis et coercendis). Modus é, antes de tudo, medida moral e não medida material, é a deliberação de ordenar uma situação em si desordenada. Médon, em grego, assinala Benvéniste, envolve não só a idéia de uma medida diretriz, mas também a de uma autoridade sábia, articulando os sentidos de premeditar, aconselhar, dominar, cuidar e governar. Refere-se a uma decisão soberana e a uma medida técnica, isto é, a uma solução eficaz conhecida graças ao exame detido de um problema particular. Assim, moderare é "tomar com autoridade medida apropriada para uma dificuldade atual" (id., ibidem) ; é reconduzir à norma uma perturbação definida.

Moderandum é o poder para conhecer e aplicar a medida, indicando o agente que tem o direito para isto: o magistrado, que impõe a medida num litígio, a auctoritas que profere a norma, o auctor que responde pela medida imposta. Eis por que, no texto espinosano, perfeito e imperfeito são proferidos pelo autor que conhece sua própria intenção e o escopo ao realizar a obra, dando forma à matéria, impondo-lhe norma e medida.

Auctor, porém, não está articulado apenas a moderandum, mas também a sui juris. Uma longa tradição, que vai de Averróis e Maimônides a Ockham, passa por Bellarmino, Grotius e Puffendorf e chega a Hobbes e Espinosa, afima que somente é sui juris aquele que possui o conhecimento do que faz e, portanto, somente o autor pode ser ou estar sui juris. Aquele que, numa situação desordenada, medita e delibera impondo-lhe uma medida (auctoritas) e aquele que sabe o que faz (auctor) estão sui juris, contra- 
riamente ao que está submetido ao desordenado e não sabe o que faz, pois vê o melhor e faz o pior para si.

No entanto, no interior dessa tradição, Espinosa (e Hobbes) introduz uma ruptura, pois auctor é retomado articulado a aítia, causa eficiente que encontra em si mesma seu próprio sentido. A ruptura é cupla: rompe com a tradição nomativa do médon aristotélico e a do moouus escolástico. É essa ruptura que o vínculo autor-perfeição inaugura e, com ela, uma mudança na idéia de sui juris articulada a um modelo técnico. Em outras palavras, rompe-se a tradição jurídico-técnica e moral que estabelecia a distinção entre ciência normativa (o agente sabe o que deve ser feito) ou razão prática (o agente causa as coisas que conhece) e ciência prescritiva (o agente conhece todos os efeitos futuros de sua ação) ou razão especulativa (o conhecimento do agente deriva-se do puro saber sobre a essência) ${ }^{(3)}$. Para chegarmos a essa ruptura devemos acompanhar o exame da prima significatio de perfeição e imperfeição.

Perfectio, derivando-se de perficere e facio, é um fazer que carrega consigo os vários significados técnicos de seus temos de origem: preparar, desenhar, representar, construir, erguer e fabricar. Perficere: concluir, acabar, terminar o que foi iniciado, perfazer a construção, ter o efeito completo da ação. Assim, perfeito se diz do realizado ou acabado, de uma obra feita e concluída segundo a intenção e o escopo de seu autor.

Auctor (Benvéniste 1, v. 2, p. 150) articula-se aos dois sentidos de augeo, o sentido clássico de aumentar e crescer, e o sentido arcaico de fazer surgir ou produzir algo do interior de si mesmo, como a Natureza em Lucrécio (e, evidentemente, em Espinosa). O autor é aquele que, em todos os campos, "pro-move", toma uma iniciativa que o faz ser o primeiro a proouzir alguma atividade e o garantidor ou responsável pelo produzido ou pela obra. O autor ér pois, causa ou princípio de ser de alguma coisa, origem do fazer-ser alguma coisa, da obra. Por isso ele e somente ele pode responder por ela e julgá-la perfeita ou imperfeita.

O sentido técnico de augeo articula-se ao sentido religioso e jurídico da auctoritas como aquela que tem o poder de fazer surgir alguma coisa e julgá-la e, dessa maneira, articula-se a moderare, tanto quando o que faz surgir é uma medida, como quando usa sua própria medida para julgar o que foi feito. Ora, ter autoridade sobre alguma coisa - medida ou obra - é ter direito sobre ela e, como observa Meillet ${ }^{(4)}$, esse direito permite que 0 autor seja referido à expressão jurídica rem suam, coisa sua, que pode usar, controlar e dispor segundo sua vontade.

Dessa maneira, o campo semântico da perfeição/imperfeição é técnico (medida, fazer), jurídico (auctoritas, auctor) e inseparável da idéia de sui juris. Em temos da metafísica espinosana, o autor só pode ser dito da causa adequada, jamais da causa inadequada.

O autor nunca está só. Sua obra, produto de sua ação, oferece-se ao olhar e ao juízo de outrem, sobretudo se o autor for o artífice e fizer a obra para um outro. Se, para o autor, sua ação e sua obra são inseparáveis, para quem a vê e julga surgem como duas realidades separadas, sobretudo se a obra é vista na ausência do autor e com o desconhecimento de sua intenção e de seu escopo. Nestas condições, julgá-la perfeita ou imperfeita não deveria ser possível ("não poderá saber se está perfeita ou imperfeita"), pois o juízo seria "uma conclusão com ausência das premissas", isto é, imagem e não idéia da dora. Todavia, a dbra é julgada. Resta saber como perfeição estado de acabamento de uma ação ou de um fazer - e imperfeição - estado de inacabamento de uma ação ou de um fazer - puderam transformar-se de descrições do que é em padrões normativos do que deve ser.

\section{Prossegue o Prefácio:}

"Mas depois que os homens começaram a formar idéias universais, a excogitar modelos (exemplaria) de casas, edifícios, torres etc., e a preferir uns modelos a outros, sucedeu que cada um chamou (appelavit) perfeito àquilo que via estar de acordo com a idéia universal que tinha formado deste gênero de coisas; chamou, ao contrário, imperfeito àquilo que via estar menos de acordo com o modelo que tinha concebido, embora, segundo o parecer dos artífices, a obra estivesse completamente acabada." 
A imaginação, como demonstraram os Livros II e III, é impotente para conservar a diferença e diversidade do múltiplo espacial e temporal, confundindo todas as coisas depois de um certo limiar da sensação e da memória. Embora seja uma afeç̧ão daquilo que há de mais particular e individual, a experiência imaginativa, por transcorrer numa região em que a mente desconhece a natureza de seu corpo e a dos corpos exteriores, assim como desconhece as causas intemas e externas das múltiplas afecções simultâneas ou sucessivas, procura vencer a fraqueza cognitiva organizando a percepção segundo os dados imediatos da sensação e da memória, agrupando-os por associação, semelhança e contigüidade. O resultado dessa operação são as idéias imaginativas universais abstratas, separadas de suas causas $^{(5)}$. Essa síntese abstrata do diverso da sensação e da memória cristaliza-se nos exemplaria. A fraqueza da imaginação memoriosa a faz também esquecer a origem dos modelos e por isso passa a tomá-los como realidades externas que orientam a ação e o juízo.

Quanto mais fraca a imagem (isto é, quanto mais abstrata a síntese e quanto mais desmemoriada a memória de sua aparição), mais imperioso o exemplar e mais imperativo o juízo. Separando autor e obra, menosprezando o juízo do autor, perdendo a singularidade da ação produtora e de seu efeito singular, a imaginação realiza três operações que a Gramática Hebraica tão bem analisou: começa perdendo o significado verbal (ou de ação) de perfectum/imperfectum; a seguir, transforma os particípios verbais em adjetivos (cristaliza-os em qualidades separadas da ação); e, finalmente, substantiva os adjetivos nos substantivos perfectio/imperfectio. Ao substantivar - substancializar abstratamente - as qualidades separadas da ação que nomeavam, a imaginação separa agente e ação, solidifica o efeito da ação num modelo e impõe este último como um valor para o julgamento do agente, da ação e da obra. Ao abstrair, a imaginação aliena o autor de sua obra, põe esta última não como efeito da causa eficiente singular que a proouziu, mas como padrão finalizado e finalista da própria ação.

Essas operações permitem passar do saber do autor sobre a ação e a obra ao juízo do espectador que julga segundo suas preferências, perfeição e imperfeição indicando uma subjetividade empírica que compara, avalia e julga desconhecendo a natureza de seus próprios juízos. Os exemplaria ga- nham, assim, independência não só face ao autor/artífice e à obra, mas também face à própria subjetividade avaliadora. Como diriam os Cogitata, passamos do uso concreto dos vocábulos ao seu uso metafórico e retórico, de um lado, e ao seu uso metafísico-abstrato, de outro. De fato, separado o auctor da ação e da obra, ele se vê separado de sua auctoritas ao mesmo tempo em que vê surgir uma nova autoridade: o uso retórico dos vocábulos faz aparecer a autoridade do discurso dos moralistas, no qual o movere, docere e delectare são construídos com os tropos e topos dos exemplaria, com a finalidade da persuasão, para "rir, lamentar e censurar os afetos". Por seu turno, o uso metafísico dos exemolaria leva à construção dos gêneros e das espécies, essências universais ou propriedades gerais das essências cujo conhecimento fica reservado à ciência prescritiva que passa a exercer a auctoritas sobre a ciência normativa.

Esse deslizamento semântico prepara um outro, inevitável:

"Nem parece haver outra razão de o vulgo também chamar perfeitas ou imperfeitas às coisas da Natureza, quer dizer, as que não foram feitas por mão humana. Com efeito, os homens costumam formar idéias universais tanto das coisas naturais como das artificiais, idéias essas que tomam por modelos das coisas e crêem que a Natureza (que estimam nada fazer que não seja em vista de um fim determinado) as considera e propõe a si mesma como modelos. Quando, portanto, vêem produzir-se alguma coisa na Natureza, que esteja menos conforme à concepção-modelo que têm de tal coisa, crêem que a própria Natureza falhou ou pecou, e deixou imperfeita essa coisa. Vemos, assim, que os homens se acostumaram chamar às coisas naturais perfeitas ou imperfeitas mais por preconceito do que por verdadeiro conhecimento delas."

Da arte à Natureza, a abstração imaginativa vai deixando seu rastro. Começa como preconceito do vulgo e temina como teoria do filósofo. Interpretando a teoria aristotélica das quatro aitiai, Heidegger (12) afima que as quatro causas são co-responsáveis pelo fazer-aparecer ou "pro-duzir" 
da coisa, e a atividade poiética não é apenas humana, mas também alcança a phýsis, só que "em sentido mais elevado", pois aquilo que está presente physei tem em si mesmo (en euató) a possibilidade do fazer-vir, enquanto o que é fabricado pelo artífice tem em outro (en alló) , isto é, no próprio artífice, a possibilidade de seu aparecer. Todavia, não porque o artífice tenha em si mesmo essa possibilidade, mas porque serve de instrumento para que a forma (eiob́s) venha inscrever-se na matéria (hylê) . A Natureza é artesã, mas de qualidade superior ao artesão humano porque nela a "pro-dução" ou "pro-moção" é espontânea, uma energéia, enquanto no artesão é apenas kínesis para suprir a carência, a kréia, do usuário.

Assim, a poiésis, como lembra Vernant (Vernant 28 e Giannotti 10), pressupõe um poder, uma dýnamis, do lado do artesão, e a kréia, do lado do usuário; entre ambos, instala-se o exemplar, a forma, o eidós que serve de norma para o artesão e de valor para o juízo do usuário. Este é a figura decisiva da produção, na medida em que esta existe para ele e, portanto, a finalidade é responsável pela solidariedade entre as quatro causas. Se o homem vem do homem por meio da semente e a casa (empírica) vem da casa (eidós) por meio do artesão, no entanto, a germinação da semente é a própria energéia atualizando seus fins potenciais, enquanto a construção da casa toma o artesão como dýnamis que só atualiza a forma na matéria porque é puxada ou empurrada pela força da carência. Todavia, uma semelhança profunda as aproxima: seja face às Formas (em Platão), seja face ao Motor Imóvel Desejável (em Aristóteles), a phýsis também é movida pela carência e pela finalidade externa transcendente que a comanda. Arte e Natureza são mímesis ${ }^{(6)}$.

É essa tradição que Espinosa tem em mira quando descreve o preconceito do vulgo. Antropocêntrica, a imaginação do vulgo projeta os exemplaria na ação da Natureza, tornando indistintos o autor humano e a autoria natural, ambos artífices a serviço da finalidade nomativo-imperativa. O preconceito do vulgo prepara, assim, o do filósofo quando este inventa e distingue duas ciências, a prescritiva e a normativa, e quando considera (como fizera Aristóteles e, depois dele, fará Locke) que o fazer não é um conhecimento enquanto ciência especulativa da prática, pois tal ciência seria conhecimento do modelo, do arquétipo que norteia o fazer. Assim, o exemplar da casa ou o da saúde antecedem lógica e cronologicamente a ação do construtor e do médico, a ação produtora finalizada tomando a causa eficiente mera causa motriz ou instrumento de mediação entre o paradigma e a obra. A verdadeira ciência do fazer encontra-se fora dele em três saberes que o antecedem: saber o que se faz (isto é, o conhecimento do exemplar), como se faz (isto ér a competência própria do ofício) e porque ou para que se faz (isto é, a finalidade como acordo com o exemplar). Os termos que perfectum sintetizara - autor, ação, obra - encontram-se separados tanto para as obras artificiais quanto para aquelas que "não são feitas pela mão do homem" e essa separação permite o juízo de valor finalista sobre as coisas naturais ${ }^{(7)}$.

Quebra-se, na tradição, o vínculo entre ser ou estar sui juris e ser auctor/opfices; entre o autor e a obra, interpõe-se o modelo que o comanda de fora; entre o autor e a ação, interpõe-se o juízo daquele que conhece o modelo e os fins da ação. Rigorosamente, o autor se toma alienus juris (ou alterius juris) e a prática - seja como poiésis seja como práxis - não pode alçar-se ao saber de si, presa na contingência que faz da ars receituário técnico e preceito moral (Rossi 19 e Mondolfo 17), mímesis em que a Natureza oferece o ideal e a arte, a norma.

Assim, a questão retórico-moral, jurídico-técnica e metafísica da perfeição/imperfeição oferece-se como discussão necessária para deslindar os fios que tecem a humana servidão, pois a cada idéia que traria uma contribuição para desfazê-la, vemos a tecelagem tornar-se mais cerrada.

Por que afirma Espinosa que a atribuição do perfeito/imperfeito à Natureza se faz "mais por preconceito" do que por conhecimento verdadeiro das coisas? Porque a finalidade extema atribuída à Natureza introduz, sub-repticiamente, a interpretação da causa eficiente como causa transitiva. Eis por que, imediatamente, Espinosa se refere ao Livro I:

"Com efeito, mostramos, no Apêndice da Parte I, que a Natureza não age tendo em vista um fim. É que aquele Ente eterno e infinito a que chamamos Deus ou Natureza age em virtude da mesma necessidade pela qual existe. Mostramos, de fato, que ele age em virtude da mesma necessidade de natureza pela qual existe (na proposição 16 
da Parte I) . Por conseguinte, a razão, ou seja, a causa por que Deus ou a Natureza age e por que existe é uma só e a mesma. E assim como ele não existe em vista de nenhum fim, assim também não age em vista de fim nenhum; da mesma maneira que não tem nenhum princípio ou fim para existir, assim também não os tem para agir."

Como o Prefácio do Livro IV, o Apêndice do Livro I ocupa-se com os preconceitos do vulgo transformados em superstição e ciência. A diferença entre os dois textos decorre do lugar onde a dechu̧ão geométrica os insere. No caso do Apêndice, a crítica aos preconceitos finalistas do vulgo se faz por referência à essência e potência de Deus, enquanto no Prefácio, a crítica se realiza a partir da natureza humana, já deduzida nos livros anteriores. Visto que o preconceito finalista equipara a imagem da ação humana e a da ação natural, Espinosa retoma as demonstrações do primeiro livro como, no Apêndice, fizera breve referência à natureza humana. Nos dois textos, o centro da argumentação é dado pela proposição 16, isto é, aquela que dá início à dedução da causalidade divina ou potência de Deus.

A proposição 16 insere-se entre duas outras cuja mediação é feita por ela: a proposição 15 (que encerra a dedução da essência de Deus), pela qual a Natureza é imanente a Deus, a essência divina sendo a unidade e unicidade da Substância infinitamente infinita, de sorte que tudo o que é, é em Deus e sem ele não pode ser nem ser concebido, Deus sendo, portanto, fonte da inteligibilidade de todo o real; e a proposição 18 (que conclui a dedução da imanência) pela qual Deus é imanente à Natureza pela necessidade de sua potência. Na proposição 15, a imanência é uma propriedade da essência divina; na 18, da potência divina ${ }^{(8)}$. A passagem de uma a outra é feita pela proposição 16: "Da necessidade da natureza divina devem resultar (sequi) coisas infinitas em um número infinito de modos, isto é, tudo o que pode cair sob um intelecto infinito".

A proposição 16 e seus corolários deduzem a causalidade divina como absoluta, necessária, universal, primeira (pois é causa sui) partindo da essência da Substância que se desdobra em infinitos efeitos em um número infinito de coisas, de sorte que o finito surge, simultaneamente, como con- sequiência da potência divina e como um efeito real dessa potência, uma coisa singular. Por sua necessidade infinita e eterna, a potência divina produz a infinidade dos seres finitos, como propriedades e manifestações da essência infinitamente infinita. A proposição 17 demonstra que a potência divina opera exclusiva e absolutamente pela necessidade livre de sua essência, não sendo incitada nem coagida à ação por nada e ninguém, agindo espontaneamente pela perfeição de sua natureza. Finalmente, a proposição 18 demonstra que a causa primeira, necessária, livre é causa eficiente não transitiva, mas imanente, os efeitos sendo diferentes dela (são modos), mas não se separam dela, exprimindo-a "de modo certo e determinado". Eis por que, no mesmo sentido em que Deus é causa de si, é causa de todas as coisas e, na Natureza, nada há que possa ser dito contingente. Culminância dessa dedução, a proposição 34 enuncia: "a potência de Deus é sua própria essência". Ou como diz o Prefácio: a causa pela qual Deus existe e a causa pela qual age é uma só e a mesma, isto é, a necessidade de sua essência infinitamente infinita.

No Apêndice, a proposição 16 era invocada não só para refutar o preconceito finalista, mas também para mostrar que a finalidade subverte a ordem da Natureza (naturam omnimo evertere), pondo o efeito como causa e a causa como efeito, isto é, põe os modos (intelecto e vontade criadores) como causas e os atributos (o que existe em si e por si e por si é concebido) como criaturas. É dupla a subversão da ordem natural: em primeiro lugar, porque, se mantido o preconceito teológico de que Deus age segundo sua vontade guiada pelo intelecto sub ratione boni, a necessidade da potência divina, propriedade de sua essência, torna-se um efeito de dois modos infinitos mediatos (intelecto e vontade); em segundo lugar, porque o modo intelecto-vontade se apropria da causa livre imanente para transformá-la em ação determinada por um fim extrínseco, destruindo a espontaneidade infinita da necessidade natural. Com isto, escreve Espinosa, destrói-se a perfeição divina. De um lado, porque a vontade (seja ela qual for) só é vontade porque age por ser determinada a agir; de outro, porque uma causa final pressupõe carência, privação e desejo, a passividade e o negativo insinuando-se no interior do infinito atual, destruindo-o. Mesmo supondo que o intelecto divino fosse intel lectus archetypus e que os exemplaria ou fins lhe 
fossem internos, seria preciso admitir uma distância entre eles e a vontade divina para que esta pudesse deliberar, escolher e agir, repondo a carência e a separação entre essência e potência, ser e ato, destruindo a substância.

Deste ponto de vista, Espinosa chega a admitir que "afastam-se menos da verdade" os que julgam que Deus age com uma vontade indiferente (isto é, Descartes) e não sub ratione boni, pois não colocam fora de Deus um modelo a que se submeteria para agir, e não "submetem Deus ao destino (fatum)". Os que afirmam a liberdade divina como liberdade de uma vontade guiada pelo intelecto negam essa liberdade e sucumbem, sem o saber, ao fatalismo que desejariam combater (e que, paradoxalmente, combatem em Espinosa). A "vontade indiferente" pelo menos tenta, confusamente, preservar a espontaneidade da essência e da potência infinitamente infinitas, ao contrário da vontade finalizada que o Apêndice designa com a célebre expressão asylum ignorantiae.

A referência ao Apêndice no Prefácio possui um alvo preciso: indicar que o nó desatado nos dois primeiros livros não pode ser reatado no Livro IV. Esse nó é a imagem da vontade como livre-arbítrio, como facultas para escolher e que, como indica a expressão "pecado original", erra, falha, cai, peca, isto é, produz imperfeições ao falhar na submissão ao modelo posto como norma e lei. Ora, a crítica espinosana não atinge apenas a versão cristã da liberdade como vontade, mas atinge também o cerne da tradição jurídica e técnica que acompanha a definição da servidão.

De fato, na modernidade a reconsideração dos objetos técnicos - ou das coisas artificiais, feitas por mão humana - está associada à reelaboração jurídica da pessoa como sujeito de direito. O fazer - dizem a tradição e a modernidade jurídicas - é um ato da vontade guiada pela razão, sem o que seria mero instinto, impulso ou inclinação. A pessoa jurídica é o sujeito inteligente dotado de vontade livre, capaz de agir em conformidade com a razão, tanto assim que os insanos e dementes não são sujeitos de direito. Essa elaboração do sujeito sui juris decorre da identificação entre jus e directum, isto é, o direito como medida que endireita e corrige o que está pervertido. Medida, agora, se diz ratio e o jus é o controle da vontade pela recta ratio. Assim, se a tradição dotou Deus de intelecto e vontade foi para que pudesse ser constituído como Pessoa ou personalidade jurídica, pois, sem isto, não se teria como afimar que ele detém o jus e o dominium sobre sua obra, o mundo.

De acordo com a tradição e a modernidade, Deus tem o dominium sobre a totalidade da criação porque sua potentia é uma potestas, uma vontade que tem o poder para fazer ou não fazer alguma coisa. Feito à imagem e semelhança do criador, o homem tem o jus/dominium sobre sua obra porque sua potentia é uma facultas, isto é, sua vontade é uma aptidão para fazer ou não fazer alguma coisa. A obra, seja ela divina - a Natureza - seja humana - o artefato -, é efeito da vontade finalizada do autor e está de jure submetida ao auctor como rem suam, é sua posse ou propriedade. O homem, abra de Deus, está sob a potestas divina que lhe concede, como escreve Suarez $(24, v .1)$, a potestas sobre a vida (um direito inalienável), o usus dos membros de seu corpo e da extensão deles nos bens que o conservam (um direito inalienável) e a possessio sobre a liberdade (por isso, um direito alienável) . O critério do jus é a conformidade entre a vontade humana faculttas - e a vontade de Deus - potestas - inscrita nos paradigmas ou modelos da ação que, por seu turno, encontra seus modelos no fazer ou na produção divina. Deus e o homem são obreiros; o homem e a Natureza são artefatos e artesãos; e a vontade, sob o intelecto que lhe dá os fins, define o sujeito sui jurisis ${ }^{(9)}$.

Diante desse imaginário metafísico, teológico, jurídico e técnico que faz Espinosa?

No primeiro livro da Ética, fazendo valer o que dissera a Meyer na carta sobre o prefácio aos Principia Philosqphiae Cartesianae - "sei o que os filólogos querem dizer com o vocábulo personalidade, mas ignoro o que os teólogos queiram dizer quando falam em personalidade divina" -, Espinosa desata os fios do imaginário do Deus pessoal, particularmente nas proposições 16 a 36 e no Apêndice. A modalização da vontade e do intelecto divinos ${ }^{(10)}$, de um lado, e de outro, a anulação da imagem da potestas divina pela idéia de potentia necessária (particularmente na proposição 35) (11) , e a crítica do imaginário dos Rectores Naturae, no Apêndice ("dotados, como o homem, de liberdade e que cuidaram em tudo que the dissesse respeito e fizeram todas as coisas para sua utilidade"), desfazem a imagem 
de Deus como pessoa e, com ela, todas as imagens técnicas e jurídicas que a acompanhavam. No Livro II, estabelecendo a identidade entre intelecto e vontade humanos, recusando que esta última seja uma faculdade da mente passando a demonstrar que ela se realiza na singularidade de cada ato de volição e que este não é senão o ato intelectual (ou imaginativo) de afimação ou negação de uma idéia, e, no Livro III, introcuzindo o conatus como essência atual do modo finito, e as idéias de causa inadequada e adequada, Espinosa desata os fios do imaginário que faziam do homem imperium imperio ${ }^{(12)}$. Com isto, desmancha a tecelagem imaginária que definia as relações homem-Deus e homem-Natureza como relações entre vontades e nas quais a vontade divina surgia como imperativo moral e a vontade humana como obrigação, pois tais relaçães, imaginadas com a mediação da relação técnico-jurídica, colocavam a obra como propriedade do obreiro, seu dominium, enquanto a relação jurídica punha a liberdade como alienável a uma outra vontade, estabelecendo a relação entre o homem e Deus como dependência ou servidão voluntária na qual, para ter a potestas sobre a vida, o usus sobre o conpo e a possessio sobre a liberdade e imaginar-se sui juris, o homem não teria outra escolha senão pôr-se como alienus juris ou alterius juris. Não é surpreendente, então, que essa tradição só possa ter uma imagem da liberdade que nada mais é senão o estar sob fortunae potestate, pois, o que hão de ser um Deus que age pela potestas de sua vontade e uma Natureza que produz coisas imperfeitas e se engana quanto aos fins, senão outros nomes ou máscaras para a Fortuna?

Dispomos, já no Prefácio, dos signos dessa desmontagem espinosana do imaginário que rege a servidão: em primeiro lugar, a relação sui jurisauctor pela mediação da perfectio como marca intrínseca da ação e da obra; em segundo lugar, a expressão fortunae potestate indicando que a diferença entre Deus sive Natura e a imagem da contingência encontra-se na absorção, pelo primeiro, da potestas pela potentia, isto é, a supressão da imagem do poder fazer ou não fazer pela idéia da ação espontânea necessária da potência divina, de sorte que a Natureza desconhece a Fortuna, restando saber porque esta reaparece na servidão humana; e, em terceiro lugar, a reintrocução da causa eficiente no plano dos modos, pela referência ao apetite humano:
"A causa a que chama final não é senão o apetite humano (humanum appetitum) enquanto é considerado como princípio ou causa primeira de uma coisa qualquer. Por exemplo, quando dizemos que a habitação foi a causa final desta ou daquela casa não entendemos outra coisa senão isto: que o homem, por ter imaginado as comodidades da vida doméstica, teve o apetite de edificar uma casa. É por isso que a habitação, enquanto considerada causa final, não é senão este apetite singular que, na realidade, é a causa eficiente, a qual é considerada como primeira porque os homens comumente ignoram as causas de seus apetites. De fato, eles têm consciência de suas ações e apetites, mas são ignorantes quanto às causas por que são determinados a apetecer alguma coisa."

A figura do autor ressurge, agora, sob a forma do apetite e na qualidade de causa eficiente, portanto, no sentido mais antigo de augeo, do fazersurgir ou "pro-duzir". A imagem do apetite é a causa final, mas sua idéia é a causa eficiente. Em outras palavras, o apetite é imaginado como causa primeira da ação e, portanto, como não-causado ou incausado, só podendo surgir, por isso, na imagem da causa final. Retomando proposição 2 do Livro III (13), Espinosa volta a afimar que os homens têm consciência de suas ações e apetites, mas ignoram as causas que os determinam a agir e apetecer. Ora, o appetitus com consciência da ação possui um nome: cupiditas, desejo, que o Livro III define como "a própria essência do homem enquanto determinada por alguma afeç̧ão a conceber ou fazer alguma coisa", o centro da definição da essência humana estando, evidentemente, no quatenus ex data affectione determinata, isto é, no estar determinada, ser causada. Essa definição da essência do homem completa a definição da essência atual de uma coisa singular qualquer como conatus, esforço para perseverar em seu ser como potência que resulta necessariamente de sua natureza determinada ou de sua essência determinada (Espinosa 6, E II, 7 d) .

Tomar o apetite-desejo como conatus humano (esforço para existir do corpo e esforço para pensar da mente) é naturalizá-lo. A naturalização não significa constatar empiricamente o fato bruto de que a natureza humana é desejosa-desejante e que o homem, como as demais coisas naturais, esfor- 
ça-se para a autoconservação. A naturalização é, antes de tudo, naturalidade metafísica, consequiência da demonstração geométrica de que o apetitedesejo-conatus é determinado por causas determinadas que o produzem em conformidade com a ordem universal e necessária da Natureza. Naturalizálo significa conhecê-lo como necessário e, desta maneira, rompendo (juntamente com Descartes e Hobbes) com a tradição que, desde Aristóteles, julgara impossível uma ciência do páthos, imaginado como contingência pura, significa também afimar a possibilidade dessa ciência, que Espinosa realiza com a geometria dos afetos e da servidão. Essa ruptura com a tradição acarreta três consequiências principais: retira o apetite-desejo (e as demais afecções e afetos) do campo que the reservara a tradição, isto é, a retórica como medicina animi; insere o apetite-desejo numa teoria geral do movimento sem recair na kínesis e na dýnamis, isto é, na teleologia e na carência; e finalmente, transtorna a tradição estoica, na qual o apetite era inclinação natural pervertida pelo desejo, tido como opinião falsa sobre o bem e o mal, pois Espinosa identifica apetite-desejo no homem e toma bom e mau como opiniões sobre o desejo.

Na tradição, por ser o apetite-desejo tomado como páthos irremediavelmente aprisionado na contingência, sem que dele fosse possível uma ciência, para ele restavam três artes: a da práxis, como educação ética pelo hábito virtuoso; a da retórica que, pelo incitare animus, comovendo, ensinando e deleitando, pretendia dobrar a índole natural do indivíduo e forçá-lo à virtude pela submissão aos exemplaria; e a medicina dos humores e caracteres que, pela classificação dos exemplaria em ingenia, intervinha sobre os excessos humorais para modelar o temperamento conforme ao engenho que the fosse próprio. Nos três casos, tratava-se de persuadir a vontade dando-lhe fins racionais aos quais, por si mesmo, o apetite não tenderia, pois, embora inclinação natural, é pervertido pelo páthos do desejo que o lança de volta à contingência nua. Assim, a tradição imaginava o apetite realizando-se num campo ambíguo, aquele no qual a Natureza (a inclinação natural) é di lacerada pelo poderio da Fortuna, restando ao moralista, ao retórico e ao médico endireitá-lo sob a recta ratio, com a doce sedução das palavras, dos exemplos e dos caracteres ideais. Aproveitando-se da inclinação natural do apetite, tratava-se de salvar o desejo das garras da fortuna criando, pelos hábitos (morais e de higiene-dieta) uma segunda natureza que fosse um senhor mais firme e seguro, mais duro, porém menos cruel do que a Fortuna. Assim, servidão e desejo eram considerados inseparáveis, seja na servidão involuntária à fortuna, seja na servidão voluntária aos exemplaria. Fm outras palavras, em vez de a servidão ser uma das formas de realização do apetite-desejo (aquela que o coloca sob o poderio da Fortuna), ela se torna idêntica a ele, a diferença entre a Fortuna e os exemplaria sendo apenas a do grau da estabilidade dos dbjetos propostos ao desejo como fins. O desejo é considerado, na tradição estoica e cristã, contra natureza e por isso o sábio (estoico) e o santo (cristão) têm um único desejo: não desejar.

Essa milenar tradição é rompida no momento em que Espinosa demonstra que o apetite-desejo é causa eficiente e não final, que é natural (possui causas determinadas que a imaginação ignora) e que a servidão não é má-vontade, mas impotência diante da potência dos afetos. Essa demonstração passa pela inserção do apetite-desejo numa nova teoria da causalidade natural (eficiente e necessária) e pela inserção do conatus numa nova teoria do movimento.

No Leviathan, Hobbes (13, I, 6, p. 119) afima que appetitus é a tradução latina para o grego hormê. Na verdade, appetitus (e com ele, cupiditas, para o homem) traduz simultaneamente oréxis e hormê. A primeira é tendência e tensão, excitação e expansão, oferenda e súplica, agarrar e atingir o alvo (donde a definição estoica de uma mobilidade interior, uma oréxis que é inclinação natural à auto-conservação e à conformidade com a Natureza). Hormê é assalto, ataque, impulso ou elã instintivo, ardor, ímpeto violento, guerrear e excitar (donde a definição estoica do páthos como hormê, impulso externo violento e contra natureza). Oréxis e hormê são modalidades de movimento interno e externo. O apetite-desejo, traduzindo simultaneamente a ambas, carrega consigo uma ambigüidade inexistente em grego.

Vindo de peto e appeto, apetite situa-se entre o ataque e a demanda, a necessidade e a falta, a atividade para fora e a passividade para dentro; avidez, agressão, carência, tendência, impulso, tensão, aspiração, arobr, agitação e inclinação, o apetite encontra-se preso no laço do movimento, enlaçado ao combate, ao conflito entre forças de atração e repulsão, à falta que quer ser preenchida e ao esforço de autoconservação. Se, na tradição, oréxis 
pertencia ao campo do éthos, e hormê ao do páthos, o fato de appetitus tracuzir ambas o coloca simultaneamente nos dois campos e como mescla de atividade e passividade. Exatamente por isso, embora seja causa eficiente, é imaginado movido pela causa final. Nossa ignorância quanto à natureza do apetite não é, pois, infundada: se o imaginamos como fim é porque, na rede das partes separadas que formam a ordem comum da Natureza, a dimensão conflitiva e agressiva do apetite o detemina como passividade e paixão, como falta e carência, ou, como escreve Espinosa sobre a paixão, envolvendo privação e negação.

Que significa Espinosa afimar que o apetite é causa eficiente e que o desejo é o apetite como consciência da ação sem consciência das causas que a determinam? Significa que o laço que prendia o apetite-desejo ao movimento se refaz num sentido inteiramente novo. De fato, na tradição (de Aristóteles à Renascença), o movimento - kínesis, dínamis e energéia é posto como carência e falta e o desejo, páthos, é sua expressão; em outras palavras, na tradição, o movimento (do mundo sublunar, dos céus, do corpo e da mente) é apetite-desejo. Com Espinosa (e Hobbes) o apetite-desejo é movimento. É conatus, movimento infinitesimal de autoconservação que age e reage à pressão ambiental, isto é, às demais partes da Natureza. Movimento já não é kínesis, dýnamis, energéia, não é processo finalizado nem carência, mas estado do corpo, propriedade ou essência de uma singularidade existente na duração. Enquanto, na tradição, o movimento carecia de uma causa (material, motriz, formal, final), agora, o movimento é a causa que se mantém indefinidamente a si mesma num espaço homogêneo que lhe oferecem a cinética e a física do princípio de inércia. O movimento é causa e efeito do movimento, mantendo-se em seu estado até que seja interrompido por outro, contrário, ou encontre um obstáculo em repouso. É geométrico (movimento do ponto que traça a linha, da linha que traça a superfície); é físico, quando acrescido do tempo e da velocidade (como o conatus cartesiano); é dinâmico, quando acrescido da força ou intensidade e da relação com a pressão ambiental (como o conatus hobbesiano e espinosano) . O apetite-desejo é conatus e causa eficiente, é ação e paixão, esforço interno de autoconservação e combate externo para autopreservação, determinado por causas necessárias, quer as conheçamos adequadamente, quer as afirmemos inadequadamente.

Esse remanejamento conceitual não deixa intacta a idéia de natureza nem a figura do autor/artífice e, portanto, a do sujeito sui juris.

O deus platônico era geômetra e fabricara a natureza segundo numero, pondera et mensura. O deus moderno é machinator, produzindo a Natureza como um relógio perfeito. Essa diferença é significativa. Ficino ${ }^{(14)}$, fascinadb por Arquimedes, dissera que o homem constrói aquilo que pode conhecer e que, com suas esferas de bronze, Arquimedes, tal o demiurgo platônico, poderia fazer novos céus, "se encontrasse instrumentos e a matéria celeste, pois foi capaz de reproduzi-los noutra matéria, graças à mesma ordem". Há, diz Ficino, uma única ciência humana capaz de criar sua própria matéria e forma: a geometria; mas a filosofia natural pode apenas "conhecer a forma e tocar de fora a matéria". Um homem-deus seria, pois, aquele capaz de uma filosofia natural geométrica, como Leonardo tentara na pintura. Será este o feito memorável de Galileu com a construção das "máquinas teóricas" que permitem, pela geometrização, criar o próprio fenômeno ${ }^{(15)}$.

Fazendo-se machinator (e não mero mechanicus), o homem poderá realizar uma filosofia natural geométrica e "tornar-se senhor e possuidor da Natureza", como queria Descartes, desde que imponha medida à sua hybris: Descartes dirá que o homem, embora capaz de fabricar máquinasmóveis, não lhes poderá dar a admirável complexidade com que Deus dotou os corpos dos animais; Leibniz dirá que, embora não haja diferença de natureza entre as máquinas artificiais e as naturais, há diferença de grau, pois estas últimas são máquinas em seus ínfimos detalhes, enquanto as primeiras encontram um limite imposto pela matéria; Mersenne dirá que, de fato, podemos conhecer as razões verdadeiras das coisas que podemos construir, mas por isso mesmo não podemos construir nenhuma das coisas construídas por Deus, das quais somente ele possui as verdadeiras razões; Hobbes dirá que "aos homens é concedida apenas a ciência daquelas coisas cuja geração depende de seu próprio arbítrio". Os três primeiros erguem um escudo contra a desmedida do auctor humano: a causa eficiente transitiva e a causa final transcendente impedem que o homem seja machinator absoluto como Deus; Hobbes ergue um outro escudo: o engenho humano é finito, limitando-se à 
ciência daquilo que ele próprio construir e que não são simples máquinas, mas autómata como ele, isto é, artefatos dotados de movimento interno e propósito, como a Cormonwealth. Em seu mundo próprio - geometria, psicologia, ética e política - o homem hobbesiano é um deus, auctor-machinator.

Espinosa avança mais um passo (aquele que o transformará em "ateu" e "blasfemador") . Deus sive Natura significa Natureza Naturante sive Natureza Naturada, o sive possuindo os dois sentidos que lhe dão as proposições I, 15 e I, 18, com as quais a causa final ( $I, 16$ e I, 17) e a causa eficiente transitiva ( $I$, 18) são eliminadas de sua potência e esta ( $I$, 34) absorve a imagem da potestas, eliminando a contingência. Por outro lado, a modalização do intelecto e da vontade, completando o percurso anterior significa Natureza Naturada sive Natureza Naturante sive autómaton. Finalmente, a modalização do homem, a identidade entre intelecto e vontade, o conatus corporal e a mente como idéia da idéia constituem o homem como autómaton (no De Emendatione: autómaton spirituale) ${ }^{(16)}$.

Como a expressão "tudo o que pode cair sob um intelecto infinito"(17) afima a plena inteligibilidade da essência e da potência divinas e como a idéia adequada afirma que o intelecto humano conhece o mesmo e da mesma maneira que o intelecto infinito ${ }^{(18)}$, o homem é um autómaton que conhece a produção divina (as duas Naturae), a sua própria produção (seu apetite e desejo) e os produtos de sua arte. Se, entre ele e Deus, permanece a diferença incomensurável entre a substância que produz as essências e existências e o modo que apenas engendra existências na ordem necessária da Natureza, no entanto, entre eles ergue-se uma identidade, não só porque o finito conhece o infinito da mesma maneira como este se conhece a si mesmo, mas também porque ambos são potências de agir-pensar que operam da mesma maneira. Em outras palavras, homem e Natureza são autores/artesãos não porque ajam em vista de fins, mas justamente porque agem pela espontaneidade (absoluta em Deus; autodeterminada no homem) de sua potência. Liberados da imagem da potestas e da facultas, Deus e homem são auctores sem serem domini, isto é, sem que seu ser e a relação entre ambos seja a da propriedade.

No caso do apetite-desejo, portanto, assim como o conpo é um conatus apto a afetar, de variadas maneiras, os corpos que o rodeiam e ser por eles afetado de múltiplas maneiras e assim como a mente é idéia (adequada ou inadequada) dessas afecções, assim também o artífice é autor dos movimentos corporais e das imagens e idéias de seu fazer. Homem e Natureza são agentes de movimentos e agentes de pensamentos/sentimentos, pois se "a ordem e conexão das idéias é a mesma que a ordem e conexão das coisas" (Espinosa 6, E II, 7 p) e se a mente "está unida à sua idéia da mesma maneira como está unida ao seu corpo" (Id., ibidem, E II, 11 p), é porque a causalidade no interior de cada atributo e no interior dos modos infinitos imediatos e mediatos tem um só e mesmo princípio, a potência divina. Essa isonomia da potência (para usarmos uma expressão de Deleuze) (Deleuze 3) faz com que o homem seja autor sui juris quando for causa adequada dos movimentos de seu corpo e do encadeamento de suas idéias-afetos, isto é, quando sua natureza for necessária e suficiente para explicar o que faz, sente e pensa, assim como a essência de Deus é necessária e suficiente para explicar Sua existência e potência.

Em contrapartida, o homem é servo ou está alienus juris (ou alterius juris) quando o que faz, sente e pensa estiver determinado pela potência das coisas e causas exteriores, potência que engendra forças incomensuravelmente superiores à sua e que o forçam a passar da condição de autómaton à de machina, produto ou efeito de causas exteriores, instrumento "dotado de voz" como o escravo de Aristóteles, submetido à vontade absoluta, caprichosa e arbitrária de seu amo, a Fortuna. Servo, o homem está submetido à tirania das paixões.

Com isto, Espinosa pode completar o exame de perfectio/imperfectio:

"Portanto, perfeição e imperfeição não são senão modos de pensar, isto é, noções que costumamos forjar porque comparamos entre si os indivíduos da mesma espécie ou do mesmo gênero. Eis o motivo por que disse antes (definição 6 da parte II) que por realidade e perfeição entendia o mesmo. Temos efetivamente o costume de reduzir todos os indivíduos da Natureza a um só gênero, a que se chama generalíssimo, a saber, à noção de Ser, noção esta que pertence a todos os indivíduos da Natureza, sem exceção. E assim, na medida em que reduzimos os indivíduos da Natureza a este gênero, os com- 
paramos com outros e descobrimos que uns têm mais entidade ou realidade que outros, dizemos que uns são mais perfeitos do que outros; na medida em que atribuímos a eles alguma coisa que envolve negação, tal como limite, fim, impotência etc., chamamo-lhes imperfeitos, pois não afetam nossa mente da mesma maneira que aqueles a que chamamos perfeitos - e isto não porque lhes falte alguma coisa que lhes seja própria, ou por a Natureza pecar. Com efeito, não pertence à natureza de alguma coisa senão aquilo que resulta da necessidade da natureza da causa eficiente, e tudo o que resulta da natureza da causa eficiente acontece necessariamente."

Nos Cogitata (como no Livro II da Ética), examinando os tipos de entes, Espinosa distinguira os entes reais e os de razão, afimando que o uso do termo ens para os segundos é um engano, na medida em que não se referem a nenhum ser, a nada exterior ao intelecto. O ente de razão (que será, posteriomente, chamado ente de imaginação) é um modo de pensar, instrumento que auxilia a mente a explicar (número, tempo e medida) , a reter na memória (gênero e espécie) e a imaginar mais facilmente (cegueira, treva, témino, limite) as coisas conhecidas. O ápice dos entia rationis são os transcendentais - ens, unum, verum, bonum - que Espinosa declara não serem seres nem afecções dos seres, mas universais abstratos.

O Prefácio retoma a crítica dos Cogitata e do Livro II aos universais abstratos, depois de deduzida a natureza da imaginação. Perfeição, imperfeição, ser, gênero, espécie, termos envolvendo negação, os entes de imaginação são modos de pensar inadequados, universais resultantes da comparação entre os indivíduos, consequiência da fraqueza da imaginação para manter a diferenciação da multiplicidade das coisas singulares que afetam o corpo. A essas abstrações, Espinosa contrapõe a definição da perfeição: "por realidade ou perfeição entendo a mesma coisa" (Espinosa 6, E II, 6 d), e a relação necessária entre a causa eficiente e seu efeito. São os dois pontos que discutira com Blyenbergh, na carta 21, declarando que a privação "não é o ato de privar", mas uma carência que "em si mesma não é nada", havendo privação quando "se nega de alguma coisa algo que julgamos pertencer à sua natureza" e negação, quando negamos "a uma coisa o que julgamos não pertencer à sua natureza".

Qual a diferença entre a idéia da perfeição e a sua imagem? A idéia da perfeição é idêntica à realidade, isto é, à natureza integral de um ser (natural ou artificial), seja porque conhecemos sua essência, seja porque conhecemos sua causa necessária. A imagem da perfeição, ao contrário, nasce da comparação entre indivíduos abstratamente reunidos no mesmo gênero ou na mesma espécie, hierarquizados "segundo a maneira como afetam nossa mente". Donde os "imperfeitos" aparecerem como os que estão privados de perfeição ou cuja natureza envolve negação. Ora, sendo a negação o juízo que nega à coisa o que não pertence à sua natureza, é um vazio de pensamento preenchido com imagens. No entanto, a imagem da perfeição não é inteiramente infundada (como, aliás, imagem alguma é infundada). Se, na mesma carta a Blyenbergh, Espinosa afirma que "quanto mais perfeição alguma coisa tem, mais participa da divindade" e se, no Livro V, demonstra que "quanto mais perfeição uma coisa tem, tanto mais age e menos padece; e inversamente, quanto mais age, mais perfeita é" (Espinosa 6, E V, 40 p) , é justamente porque os perfeitos e imperfeitos não se referem, como supõe a imaginação, a graus de realidade entre essências pertencentes a um mesmo gênero, mas se referem a graus da potência para ser e agir de uma mesma essência.

É isto que estabelece o vínculo metafísico entre perfectio/imperfectio e o campo afetivo, explicando porque a discussão dos termos é feita no Prefácio sobre a servidão humana. De fato, a paixão é uma idéia confusa pela qual a mente afirma a potência de existir maior ou menor de seu corpo e pela qual é levada a desejar uma coisa mais do que outra. A oscilação da realidade-perfeição do corpo e da mente depende, no caso da paixão, da força com que ambos são afetados e dominados pela força das coisas-causas exteriores, isto é, decorre de affectum viribus.

Eis por que é necessário determinar "o que há de bom e mau nos afetos":

"Bom e mau também não indicam nada de positivo nas coisas consideradas em si mesmas, nem são outra coisa senão modos de pensar que formamos por compararmos as coisas umas com as outras. $\mathrm{Na}$ 
verdade, uma só e mesma coisa pode ser ao mesmo tempo boa e má e ainda indiferente. A música, por exemplo, é boa para o melancólico, má para o que se lamenta, mas para o surdo não é boa nem má."

Como no início do Prefácio, parecemos estar de volta à tradição estoica: aí estão as coisas boas, más e indiferentes. Todavia, uma primeira diferença já se anuncia, pois Espinosa afirma que bom-mau, bem-mal são modos de pensar nascidos da comparação entre as coisas, enquanto o estoico afimma a existência em si do bem, isto é, do que está em conformidade com a Natureza, além de afimar a inexistência em si do mal, isto é, do que é contra natureza e portanto não pode existir. As paixões, para o estoico, páthos e perturbatio animi, são contra natureza, não existem senão como opiniões falsas sobre o bem e, portanto, nada há nos afetos que permitiria determinar o que neles há de bom ou mau. Espinosa, pelo contrário, não só deduz a realidade e a naturalidade dos afetos (ativos e passivos) , como ainda inverte a concepção estoica, isto é, bom e mau é que são opiniões sobre os afetos e as coisas. Eis por que, para o estoico, as mesmas coisas são sempre boas, ou sempre más ou sempre indiferentes, enquanto para Espinosa uma mesma coisa pode ser boa, má ou indiferente.

Embora meros modos de pensar ou de imaginar, "temos de conservar esses vocábulos", prossegue o Prefácio.

"É que, visto desejarmos formar uma idéia de homem (ideam hominis) que consideraremos como um modelo da natureza humana (naturae humanae exemplar), ser-nos-á vantajoso conservar estes vocábulos no sentido em que disse. Por bom, por conseguinte, entenderei, no que se segue, o que sabemos com certeza ser um meio para que alcancemos cada vez mais o modelo da natureza humana que nos propomos. Por mau, aquilo que sabemos com certeza que nos impede de alcançar o mesmo modelo. Assim, diremos que os homens são mais ou menos perfeitos, mais ou menos imperfeitos na medida em que se aproximarem mais ou menos desse exemplar."
O texto espinosano é desconcertante. Espinosa parece trazer de volta tudo quanto fora objeto de sua crítica, deixando o leitor perplexo: se os "vocábulos" vão ser retidos, se com eles retornamos à idéia do exemplar, se com eles retornamos às imagens da perfeição e da imperfeição como comparação face ao modelo, então por que as críticas anteriores? Não teria bastado começar onde o Prefácio termina?

Sem dúvida, somente ao término do Livro IV poderíamos responder plenamente a essas indagações. No entanto, a leitura dos Livros II e III já nos oferece as primeiras respostas e nos orienta na compreensão das definições e do axioma da quarta parte da Ética.

\section{Transição do Prefácio às definições}

Bom e mau, tanto no Prefácio quanto nas definições 1 e 2, são definidos como saber certo: "por bom entenderei o que sabemos com certeza sernos útil" (Espinosa 6, E IV, 1 def.); "por mau, ao contrário, aquilo que sabemos com certeza que nos impede de nos tornarmos senhores (compotes) de um bem qualquer" (Espinosa 6, E IV, 2 def.) . Observemos, antes de mais nada, que as duas definições não são simétricas, pois a segunda não declara que mau seria o que sabemos com certeza ser-nos prejudicial ou nocivo, mas o que sabemos com certeza que nos impede de nos tornarmos senhores de um bem qualquer. O termo empregado por Espinosa é compotes, portanto, um derivado de potio (colocar sobre o poder de) e de potior (assenhorarse, ser senhor de). Compotes é aquele que consegue um bem, torna-se senhor dele e pode fruí-lo, pois esse bem é res sua e sobre ele o sujeito é sui juris. Assim, indicando impotência para um bem, a definição de mau retoma, noutro registro, a definição da servidão.

Em que, porém, essas definições não são um retorno a imagens criticadas? É o uso das expressões "saber certo" ou "sabermos com certeza" que nos indica a resposta. No Livro II, ao expor a teoria dos gêneros de conhecimento, Espinosa demonstra que o segundo gênero, isto é, a razão ou o raciocínio discursivo, é um conhecimento certo, um saber certo cujo dbjeto são as idéias adequadas das propriedades gerais e comuns às partes e ao 
todo, ou do que se encontra igualmente na parte e no todo. A razão é o saber certo das noções comuns. Na proposição 37 do Livro II, lemos que "o que é comum a todas as coisas e existe igualmente (aeque) no todo e nas partes, não constitui a essência de nenhuma coisa singular"; na proposição 38 do Iivro II, enuncia-se que "as coisas que são comuns a todas as coisas e existem igualmente no todo e nas partes só podem ser concebidas adequadamente"; por sua vez, a proposição 39 do Livro II afirma que "aquilo que é comum e próprio ao corpo humano e a certos corpos exteriores, pelos quais o corpo humano é habitualmente afetado, e é comum e próprio a cada uma de suas partes assim como ao todo, sua idéia existe adequada na mente"; e, finalmente, na proposição 40 do Livro II, lemos: "todas as idéias que resultam na mente das idéias que nela existem adequadas, são também adequadas".

O naturae humanae exemplar de que fala o Prefácio não é, pois, uma imagem. Não é uma idéia universal de uma essência universal (pois não existem essências universais). Não é um transcendental (pois não é uma afecção geral e abstrata dos seres) . Não é um gênero nem uma espécie (pois não é uma imagem nascida da comparação imaginativa de coisas particulares numerosas que a imaginação confunde e generaliza numa abstração) . É uma notio communis, idéia adequada das propriedades comuns que existem igualmente no todo e em suas partes, daquilo que, sendo comum, convém às partes entre si e entre elas e o todo. A noção comum não é idéia de uma essência singular, mas um sistema de relações necessárias entre as partes com o todo, delas entre si e dele com elas. O exemplar da natureza humana a ser proposto origina-se na dedução ou construção geométrica das relaçães de conveniência e contrariedade entre certas partes da Natureza, no caso, entre as partes humanas da Natureza. Bom se diz do conhecimento certo das relações entre as partes que contribuem para que uma parte humana da Natureza tome parte no sistema de conveniências e concordâncias que a constituem como parte dele e que o constituem como todo. É o saber certo dessas relações que é útil. Mau se diz do conhecimento certo das relações entre partes que são contrárias ou discordantes entre si e impedem que a parte humana da Natureza tome parte no sistema necessário das relações entre ela e o todo. Mau é não conseguir ter parte nesse sistema, mantendo- se como parte isolada e abstrata, pars partialis que não consegue tornar-se pars communis.

Porque bom e mau são o saber certo de propriedades gerais que existem igualmente no todo e nas partes, propriedades comuns a todas as partes e ao todo, propriedades convenientes às partes e propriedades contrárias às partes, Espinosa pode afirmar, no Prefácio, que "bom e mau não indicam nada de positivo nas coisas consideradas em si mesmas", isto é, não são conhecimento de essências singulares, mas de relações necessárias entre as partes singulares.

Assim, enquanto imagens das coisas, bom e mau são modos de pensar e Espinosa é nominalista. Porém, enquanto saber certo do que nos é útil e do que nos impede de sermos sui juris, bom e mau, sem indicar nada de positivo nas próprias coisas, indicam fomas de relações entre elas e, nessa perspectiva, Espinosa não é nominalista nem relativista, pois bom e mau se referem à qualidade dos afetos segundo nos permitam ou nos impeçam de realizar ações que nos liberem da abstração da pars partialis. Podemos, assim, compreender porque bom e mau são definidos de maneira diferente. Vimos que o jus, quando se articula a directum, exige que o direito seja proferido - é um dictamen - e como o que é proferido é a medida (modus, médon), é recta ratio. Assim os dictaminia rationis expostos no Livro IV são os moderadores dos afetos, de sorte que a razão, por meio das noções comuns, oferece as medidas: bom é medida; mau, o que nos impede de medida, é o ficar aquém da medida. Bom nos torna compotes e sui juris; mau, nos mantém na servidão.

Espinosa, portanto, não regride ao que fora objeto de sua crítica, mas avança na explicitação do que dissera na abertura do Prefácio: determinar o que há de bom ou mau nos afetos, conhecimento que tem como baliza a noção comum de natureza humana. Somente assim saberemos com certeza o que está em nosso poder (como e quando somos sui juris) e o que está sob - poderio da fortuna (como e quando somos alterius juris). Ou, como diz o Prefácio, quando os homens são mais ou menos perfeitos, mais ou menos imperfeitos.

Que significam esse "mais" e esse "menos"? 
"Efetivamente, deve-se notar antes de tudo que quando digo que alguma coisa passa de uma perfeição maior a outra menor, ou inversamente, não entendo por isso que mude de essência ou de forma, passando a uma outra. De fato, cavalo, por exemplo, tanto se destrói se se mudar em homem, como se se mudar em inseto. É o seu poder de agir (agendi potentiam), enquanto entendido como sua própria natureza (quatenus haec per ipsius naturam intelligitur), que concebemos como aumentado ou diminuído. Finalmente, por perfeição em geral entenderei, como disse, a realidade, isto é, a essência de uma coisa qualquer enquanto ela existe e age de uma determinada maneira, sem qualquer referência à sua curação. Na verdade, nenhuma coisa singular pode dizer-se mais perfeita por perseverar mais tempo na existência. É que a duração das coisas não pode ser determinada pela essência, visto que a essência de uma coisa não envolve nenhum tempo certo e determinado de existência; mas uma coisa qualquer, quer ela seja mais perfeita quer menos, poderá perseverar na existência com a mesma força por que começou a existir, de tal sorte que, sob este ponto, todas as coisas são iguais".

Perfeição e realidade são uma só e mesma coisa, de sorte que o "mais" e o "menos" não se referem a mudanças da essência (passar de uma natureza ou forma a outra), mas a mudanças na essência enquanto aumento ou diminuição de sua potência de existir e agir. É a variação na intensidade do conatus. Essa variação não pode ser determinada temporalmente, pois, como demonstra a proposição 8 do Livro III, "se o esforço de perseverança na existência envolvesse um tempo limitado que determinasse a duração da coisa, então resultaria da própria potência em virtude da qual a coisa existe que ela já não poderia existir depois desse tempo limitado, mas deveria ser destruída, o que é absurdo", pois o conatus é uma positividade intrinsecamente indestrutível que só pode ser destruída ou desaparecer da existência sob a ação de causas externas mais poderosas do que ele e contrárias a ele.

Em outras palavras, o tempo de duração não só não constitui o ser de uma essência singular, como ainda tentar conhecer a perfeição da essência através da duração levaria a confundir, de um lado, realidade e quantidade de existência, e, de outro lado, perfeição e pemanência indefinida no tempo, confusão que leva a imaginação a afimar que a mente é mais perfeita do que o corpo porque seria imortal e ele, mortal.

Afirmar que perfeição e tempo de duração são diferentes significa dizer que a perfeição está referida à potência de existir e de agir e, portanto, vincular internamente a perfeição da coisa singular à perfeição de sua causa (no caso, à potência divina, tal como demonstrada na proposição 16 do Livro I), ainda que cada essência singular venha à existência pela mediação de outras existências singulares (Espinosa 6, E II, 45 e). Significa, ainda, como lemos no escólio da proposição 45 do Livro II, que "a força com a qual uma coisa persevera na existência decorre da necessidade eterna da natureza de Deus", tal como esta é demonstrada na proposição 24 do Livro I ${ }^{(19)}$. Significa, em terceiro lugar, que a relação da essência com a existência só é uma relação interna necessária quando a duração deixa de ser apreendida externamente (como quantidade de tempo) para ser apreendida internamente como o próprio conatus.

Aumento e diminuição da perfeição referem-se, pois, ao aumento ou diminuição da força do conatus em sua relação com as forças exteriores, de sorte que a força ou fraqueza das afecções conporais e a força e fraqueza dos afetos da mente determinam a perfeição maior ou menor. Assim, a conclusão do Prefácio nos reconduz à sua abertura: a servidão é impotência humana (fraqueza) para moderar e refrear a força dos afetos, deixando-nos à mercê da fortuna.

\section{Definições e Axioma}

Compreendemos, então, porque Espinosa poderá, sem contradição, definir o apetite como "fim pelo qual fazemos alguma coisa" (depois de haver afimado que tomá-lo como fim era ignorância da causa), fazer reaparecer o contingente e o possível (expulsos como imagens no Livro I, nos Cogitata, no De Emendatione e na Korte Verhandeling) (20), e manter a definição da virtude pela potência, tal como o fizera no Livro III. 
As definições, que, à primeira vista, pareceriam desordenar a demonstração geométrica efetuada nos livros anteriores, na verdade, a reordenam segundo um princípio novo que não pudera operar até aqui: a potência (fraca ou forte) da imaginação e a potência (fraca ou forte) da razão. Assim, as definições se distribuem aos pares: à definição de bom-mau, que está referida à razão, se contrapõe a definição de contingente-possível, que está referida à imaginação; à definição do apetite como fim, que está referida à imaginação, contrapõe-se a definição da virtude, que está referida à razão; à definição dos afetos contrários e a das afecções deteminadas temporalmente, que estão referidas à imaginação, contrapõe-se, ainda uma vez, a definição da virtude como potência interna, que está referida à razão. As definiçães do contingente, do possível, dos afetos contrários, das afecções no tempo e do apetite como fim formam o campo da servidão e da Fortuna; as definições de bom, mau e virtude formam o campo da razão e da liberdade racional. A unidade dessas definições é trazida pelo axioma, chave do Livro IV.

O axioma que sustenta a dechucão geométrica do Livro IV enuncia que "não existe na Natureza nenhuma coisa singular tal que não exista uma outra mais forte e poderosa do que ela. Dada uma coisa qualquer, é dada outra mais poderosa pela qual a primeira pode ser destruída". Por sua vez, a proposição 2 declara que "padecemos na medida em que somos uma parte da Natureza que não pode ser concebida por si mesma sem as outras", enquanto a proposição 3 afirma que "a força pela qual o homem persevera na existência é limitada e infinitamente superada pela potência das causas externas". Finalmente, na proposição 4, Espinosa demonstrará que "é impossível que o homem não seja uma parte da Natureza e que não possa sofrer outras mudanças senão aquelas que podem ser compreendidas somente por sua natureza e de que é causa adequada". O axioma põe no centro da dechção a idéia de partes da Natureza mais e menos poderosas.

A idéia de parte não surge subitamente no Livro IV, mas já foi introduzida desde o Livro II. Ali, o corpo e a mente foram deduzidos como partes - a mente como parte do intelecto infinito de Deus e o corpo como parte da facies totius Naturae, isto é, da Natureza extensa entendida como um único Indivícuo (proposição 13 do Livro II, lemas, axiomas e defini- ções) . O lema 1 define o corpo como coisa singular e a definição, após o axioma 2, o define como indivíduo quando todos os seus componentes atuam como uma causa única e se tornam, por isso, constituintes dele como individualidade. A ele encontra-se unida a mente, disto resultando que ela não é simples, mas composta de muitas idéias. Assim, no Livro II, a parte é uma singularidade individual complexa. No entanto, na proposição 24 do Livro II, lemos que "a mente humana não envolve um conhecimento adequado das partes do corpo humano". Seu conhecimento é inadequado porque alcança apenas as disposições atuais de seu corpo, afetado por outros e afetando-os. A origem dessa inadequação encontra-se no fato de que o corpo humano não é causa das partes que o compõem nem da integração entre elas, pois dependem da causalidade operante na ordem comum da Natureza. Embora o conhecimento adequado do corpo e de suas partes exista em Deus enquanto infinito, não existe na mente porque, neste nível, Deus não constitui a essência determinada ou singular da mente, mas constitui a essência geral da Natureza Naturada. Corpo e mente são apreendidos como produzidos por Deus ao mesmo tempo em que Ele produz todos os corpos e todas as mentes da Natureza, não constituindo a essência singular de nenhum deles. Percebida inadequadamente, a individualidade é imaginada como parte separada de todas as outras da Natureza. No escólio da proposição 35 do Livro II, esta separação ou este isolamento se manifesta como privação de conhecimento verdadeiro e o exemplo escolhido por Espinosa é o da ilusão da liberdade (a imagem da vontade livre como um poder para fazer ou não fazer alguma coisa), isto é, privação do conhecimento das causas que determinam as ações de cada parte da Natureza.

No Livro III, no escólio da proposição 3, lemos que "as paixões só se referem à mente quando esta tem algo que envolve uma negação, isto é, quando a mente é considerada como uma parte da Natureza (pars Naturae) que não pode ser percebida clara e distintamente por si mesma sem as outras partes", afimação que é retomada na proposição 2 do Livro IV: "somos passivos enquanto somos uma parte da Natureza (pars Naturae) que não pode ser concebida por si mesma sem as outras". Na demonstração desta proposição Espinosa usa o temo partialis para referir-se ao tipo de causalidade que opera na paixão, afirmando que somos passivos quando 
somos causa partialis, isto é, cujos efeitos não podem ser deduzidos das leis de nossa natureza. A paixão põe uma parte que não pode ser concebida sem as outras e que não encontra em si mesma a causa totalis do que sente, faz ou pensa.

Assim, desde o Livro II, ser parte e ser causa parcial estão na origem da inadequação - no conhecimento - e da passividade - no sentimento. No Livro IV, esta situação, acrescida de duas novas determinaçães - a de que para cada parte singular haverá outra mais potente do que ela, e a de que a parte humana não pode ser concebida sem as outras cuja potência ultrapassa infinitamente a sua - será o fundamento da servidão.

Todavia, "ser parte" ainda possui um outro sentido. Como observamos anteriormente, nas proposições 37, 38, 39 e 40 do Livro II, a pars é decuzida como integrante de uma totalidade, compartilhando com ela e as demais partes propriedades comuns que "existem igualmente (aeque) na parte e no todo", isto é, as noções comuns, conhecidas adequadamente pela razão. As relações de conveniência e contrariedade entre as partes tornam possível a dedução de uma teoria geral da individualidade conporal (física e fisiologia dos conpos, no Livro II), uma teoria geral das afeções conporais e afetos (lógica dos sentimentos na e da mente, no Livro III) e uma teoria geral sobre bom e mau - a força dos afetos - que permite decuzir a servidão e formular a noção de natureza humana virtuosa, sob a direção da razão, no Livro IV. Há, ainda, um último sentido de pars, desenvolvido no Livro V. Na proposição 36, Espinosa demonstra que "o amor intelectual da mente por Deus é o próprio amor de Deus com que este ama a si mesmo, não enquanto é infinito, mas enquanto pode ser explicado pela essência da mente humana considerada sob o aspecto da eternidade; isto é, o amor intelectual da mente por Deus é uma parte do amor infinito (pars est infinitis amoris) com que Deus ama a si mesmo". Aqui, a parte não é aquela produzida por Deus ao produzir todas as outras, nem é a parte tendo propriedades comuns com o todo, mas é essência singular de uma coisa singular constituída por Deus enquanto modificado nela e que possui a mesma (ipse) qualidade do infinito que nela se exprime. Passamos da região do aeque à do ipse (o mesmo no finito e no infinito) : a pars é um ato (amor intelectual) idêntico nela e em Deus. Não é mais pars partialis nem pars communis: é pars singularis ${ }^{(21)}$.

Quando acompanhamos a dedução espinosana pelo prisma da idéia de parte, podemos observar que se desdobra sempre em dois níveis: no da mente unida ao seu corpo e como afi mação da existência atual de seu corpo (idéia do corpo) ; e no da mente diferenciada de seu corpo, afimando a essência dele e de si mesma (idéia da idéia). Ora, esse duplo ponto de vista dedutivo em lugar de separar corpo e mente, fortalece a união de ambos. De fato, uma das inovações maiores da Ética está em demonstrar o modo da união corpo-mente recusando que haja atuação recíproca de um sobre outro, de sorte que passividade e atividade se referem sempre a ambos e por inteiro: a um corpo passivo corresponde uma mente passiva; a um corpo ativo corresponde uma mente ativa. E vice-versa. Visto que as idéias da mente estão unidas a ela como ela está unida ao seu corpo, a diminuição e o aumento da potentia agendi do corpo repercute na potentia cogitandi da mente. Isto significa que a passagem da mente da inadequação para a adequação racional e para a adequação reflexiva exige e pressupõe o aumento da potência de agir do corpo. Esse aumento se realiza em duas esferas diversas: no aumento da potência do conatus por meio das relações de conveniência entre corpos com propriedades comuns (aumento racional da potência de agir) e no aumento das aptidões do corpo para afetar e ser afetado por outros de múltiplas maneiras simultâneas sem ser destruído por eles nem destruí-los (aumento autônomo da potência de agir). Donde, "quem tem um corpo apto para o maior número de coisas simultâneas, tem uma mente cuja maior parte é eterna" (Espinosa 6, E V, 34 p). Em outras palavras, o aumento da potência de ser e agir decorre da diminuição da dependência (abstrata) de outras partes e do crescimento da conveniência (concreta) das relações necessárias entre as partes e, sobretudo, da autonomia (concreta) da parte como causa interna de seus efeitos.

A diferença entre dependência (alterius juris) e autonomia (sui juris) determina a diferença entre, de um lado, servidão, conhecimento inadequado, causa inadequada e, de outro lado, liberdade, conhecimento adequado e causa adequada. Justamente porque, do lado da imaginação, caminham juntas abstração, inadequação, passividade e dependência, e do lado da razão e 
da reflexão, caminham juntas concreção, adequação, atividade e autonomia, o Prefácio do Livro IV retornará ao Livro I para reforçar, antes de tudo, a autonomia de Deus ou da Natureza Naturante, isto é, a causa sui, livre, total, imanente, primeira e absoluta. Com efeito, se a servidão é ilusão de independência da parte isolada sob a dependência real, e se a liberdade é a certeza da autonomia da parte comum enquanto tendo parte no todo (Livro IV) e da parte singular enquanto tomando parte no todo (Livro V), é preciso que este seja demonstrado como realidade absolutamente autônoma e, por isso, deduzido da potência autodeteminada da Substância ou da identidade entre a potência e a essência de Deus. A causa sui, enquanto causa imanente, exprimir-se-á na causa adequada racional (Livro IV) e na causa adequada intelectual (Livro V), isto é, manifestar-se-á na parte.

Na servidão, a pars partialis encontra-se sob o signo da privação e da negação, marcas próprias da paixão. Privação, porque a idéia inadequada e a causa inadequada não estão aptas a dar a razão total ou a causa total do efeito, faltando-lhes autodeterminação. Negação, porque a pars não pode ser concebida sem as outras na ordem comum da Natureza. Em resumo, a origem do que se passa na parte passiva está fora dela, no que não é ela. Privação e negação transformam cada parte numa parte contrária às outras e, na servidão, numa parte contrária a si mesma: "por afecções diversas entenderei os afetos que puxam o homem em sentidos contrários", enuncia a definição 6. Como pode ser isto possível, se Espinosa insiste em que "coisas de natureza contrária não podem coexistir no mesmo sujeito, pois uma pode destruir a outra" (Espinosa 6, E III, 5 p) e se o conatus é uma positividade ou uma potência afimativa intrinsecamente indestrutível, que afasta ou exclui toda contrariedade interna?

No entanto, durante a decução dos afetos, no Livro III, Espinosa também insiste em que uma mesma coisa pode ser, por acidente, causa de afetos contrários num mesmo sujeito ou em vários sujeitos e, na dedução da servidão, no Livro $I V$, insiste em que os mesmos afetos podem arrastar um mesmo sujeito em direções contrárias. Na vida afetiva, "somos agitados de múltiplas maneiras pelas causas exteriores e, como as ondas do mar, agitadas por ventos contrários, flutuamos ignorantes de nossos reveses e de nosso fado". (Espinosa 6, E III, 59 e)
No Livro IV, Espinosa demonstra que afetos são contrários quando aumentam ou diminuem a potência de agir (Espinosa 6, E IV, 7 d) , que uma coisa pode ser dita má naquilo que tem de contrário à nossa natureza ( Id., ibidem, E IV, 30 p) e que, na paixão, os homens são contrários uns aos outros ( $I d$. , ibidem, E IV 34 p). Em suma, se a indestrutibilidade intrínseca do conatus exige que o contrarium the seja sempre externo, como explicar sua interiorização? Como a servidão pode comportar contrariedade se, ainda que seja a forma extrema da inadequação, é uma forma de afimação do conatus na existência $e$, portanto, deveria expulsar a contrariedade, em vez de ser habitada por ela?

Todavia, o leitor atento observará que Espinosa também insiste em dois pontos capitais: por um lado, na afirmação de que afetos contrários podem ser produzidos em nós por uma coisa qualquer por acidente, motivo pelo qual, nas definições 3 e 4 do Livro $I V$, introduz o contingente e o possível na dedução da servidão; mas, por outro lado, insiste na diferença entre diversume contrarium, distinção que será indispensável para que a razão conheça o que "há de bom e mau nos afetos".

Diversumé o diferente por essência (os atributos são diversos; os modos finitos são diversos por seus atributos e são diversos deles justamente porque deles recebem a essência e a potência) . Contrarium se diz da diferença de intensidade na potência de coisas de mesma natureza, pois as coisas que nada possuem em comum são diferentes por essência e não são contrárias nem concordantes entre si.

Na medida em que o conatus é a essência atual de um indivíduo, este é diversum dos demais pela diferença de suas potências atuais. Os diversos podem convir ou ser contrários. Convêm entre si pelo que possuem em comum (os atributos possuem em comum a potência de causa sui que os unifica como constituintes da essência do absoluto; as partes do corpo convêm porque têm em comum a causalidade eficiente do conatus que os unifica como constituintes de um único corpo). São contrários quando, embora convenientes por suas essências, diferem pela intensidade de suas potências e é essa diferença que, na ordem comum da Natureza, toma-os diferentes, contrários. Contrário, portanto, se diz das forças (vis) extemas e intemas cuja intensidade varia em cada parte (da Natureza) que, isolada, é incomensura- 
velmente mais fraca do que as causas extemas e luta com elas para afimarse na existência. No caso da parte humana da Natureza, contrarium está referido às forças dos afetos ou, como diz o título do Livro IV, De affecturum viribus. A contrariedade não se encontra no interior da essência, mas na variação da intensidade de sua potência sob os efeitos da causalidade externa de potências cujas forças são superiores e contrárias às suas.

Essências não são contrárias; a força de suas potências, sim. É essa contrariedade que as definições 3 e 4 chamam de contingente e possível, pois a parte parcial e contrária está sob o poderio de forças externas mais potentes e contrárias à sua natureza e por isso a servidão é a humana impotência sobre os afetos que nos lança à fortunae potestas. Não padecemos nem somos servos porque somos uma parte da Natureza, mas enquanto (quatenus) somos uma parte que não pode ser concebida sem as demais, isto é, enquanto (quatenus) não pode ser concebida por si mesma e cuja potência é incomensuravelmente menor do que as delas. Passividade, heteronomia e servidão referem-se à coisa singular enquanto parte determinada pelo que não é ela e pelo que é contrário a ela ${ }^{(22)}$.

O axioma dá pleno sentido ao reaparecimento do contingente e do possível no Livro IV. Como observamos, nas obras anteriores e no Livro I da Ética, Espinosa recusa as noções de contingência e possibilidade objetivas, reduzindo-as a imagens resultantes de nosso desconhecimento de uma contradição interna que torna uma essência impossível, bem como de nosso desconhecimento das causas necessárias de uma existência cuja essência sabemos não ser internamente contraditória. Vimos também que a tradição fizera do contingente e do possível noções indispensáveis para a prova da liberdade divina como potestas e da liberdade humana como facultas, isto é, em ambos os casos, como um poder para fazer ou não fazer alguma coisa. A rejeição espinosana do contingente e do possível segue a rejeição das noções de potestas divina e facultas humana, Espinosa dedicando-se à demonstração da contradição/não-contradição da essência (no lugar da contingência) e da presença/ausência da causa (no lugar da possibilidade) . Afastando a perspectiva voluntarista, bem como a fatalista, Espinosa reintroduz o possível e o contingente no Livro IV, porque, agora, apresenta o campo imaginativo da fortunae potestas, urdido na teia da possibilidade e da con- tingência, pois a servidão se exprime numa subjetividade empírica dilacerada - "vejo o melhor e o aprovo, mas sigo o pior" -, maneira pela qual a pars partialis et contraria experimenta seu isolamento e sua fraqueza no conjunto das forças naturais mais numerosas e mais poderosas do que ela e contrárias a ela. A parte isolada e fraca é atingida pelas forças externas sem que possa compreendê-las nem compreender-se no todo necessário da Natureza. Estar alienus juris ou alterius juris é exatamente experimentar o embate com a exterioridade como acidental e fortuito.

O reaparecimento do contingente/possível é também indispensável à economia da decução geométrica porque a distinção entre ambos determina o primeiro movimento do saber certo sobre o bom e o mau: os afetos terão força diferente conforme se refiram a coisas imaginadas como necessárias, contingentes ou possíveis, sendo fundamental distingui-las para e na dedução da intensidade afetiva, uma vez que são decisivas para a variação desta intensidade. Em outras palavras, a determinação imaginativa da força do afeto segundo a imagem necessária, contingente ou possível das coisas exteriores institui o campo no qual a razão irá operar para vencer a Fortuna.

A tarefa da razão - isto é, daquilo que é a essência da mente quando conhece clara e distintamente (Espinosa 6, E II, 40 e) - consistirá em determinar o que "há de bom e mau nos afetos", ou seja, em avaliar quais aumentam e quais diminuem a potência de agir do corpo e de pensar da mente, quais são contrários ao homem e quais the são convenientes, como afastar os primeiros e fortalecer os segundos. Como auctor moderator, a razão pesa, medita, avalia, julga e oferece a medida, a moderação, passando do que é contrário por acidente (a Fortuna) ao que é conveniente por natureza.

O axioma oferece uma visão da Natureza como conjunto de coisas singulares articuladas num sistema de forças e poderes desiguais em conflito, os mais fracos podendo ser destruídos pelos mais fortes e potentes. Será esta a descrição do estado de natureza, no final do Livro IV, e por isso o homem sui juris neste estado é uma abstração, como dirá o Tratactus Politicus. No "sistema da servidão" tudo é abstrato: a individualidade e a alteridade belicosas se constituem por privação e negação e será compreensível que a imaginação produza uma teoria do direito civil como relação 
entre proprietários, na medida em que imperium e dominium definem a imagem do sujeito sui juris.

O axioma organiza o Livro IV em duas linhas divergentes de proposicões: a primeira, que reúne as proposições 1, 8, 14, 15, 16 e 17, refere-se ao conhecimento; a segunda, que reúne as proposições 2 a 7, 18 e 19, refere-se à finitude da parte humana da Natureza, isolada das demais e submetida à Fortuna ou à servidão. Somente a partir da proposição 20, quando a virtude entra em cena, a correlação de forças se transforma e dá início a uma terceira série de proposições sob a direção da razão que, retomando os afetos, passa a avaliá-los no que têm de bom e mau.

o Livro IV é passagem e travessia. Passagem da servidão e do poderio da fortuna à liberdade racional e à potência da virtude ("conhecer é a virtude suprema da mente") . Travessia porque a física das afeccões e a lógica dos afetos exigem que o percurso encontre um ponto de apoio novo e este se localiza numa região perigosamente frágil.

De fato, esse ponto de apoio é o desejo e não a razão, e o desejo se realiza originariamente como paixão e servidão. Do ponto de vista afetivo, é irrelevante que a razão demonstre a necessidade universal da Natureza e da natureza humana, pois a imaginação opera na esfera da particularidade, da contingência e da contrariedade, únicas reais para ela. Tratar os afetos como naturais significa não só demonstrar que possuem causas naturais determinadas, mas ainda demonstrar a necessidade com que são vividos e experimentados imaginariamente numa ordem que não é a das conexões universais necessárias, mas fortuna, ordem empírica da finitude abstrata. Fis por que, na mais antiintelectualista das proposições da Ética, lemos: "o verdadeiro conhecimento do bom e do mau, enquanto verdadeiro, não pode refrear nenhum afeto, a não ser quando este conhecimento é considerado um afeto" (Espinosa 6, IV, 14 p) . Demonstrada a fraqueza da razão face aos afetos, a ela só restará tornar-se um afeto também para realizar a travessia da servidão. E esse afeto será o desejo. Travessia difícil, pois a razão precisa encontrar na própria paixão e na servidão o instrumento que fará de um sujeito alterius juris, o sujeito sui juris, auctor/agente de suas ações.

A chave da relação razão-desejo encontra-se na relação razão-virtude e desejo-virtude, a partir da definição 8: "por virtude e potência entendo a mesma coisa, isto é, a virtude, enquanto se refere ao homem, é a própria essência ou natureza do homem, enquanto tem o poder de fazer algumas coisas que só podem ser compreendidas pelas leis de sua natureza".

Virtus e potio, força e potência, são uma só e mesma coisa quando o homem é causa adequada de suas ações e idéias. Ora, no escólio da proposição 40 do Livro II, Espinosa afima que a essência da mente é a razão. Esta não é uma faculdade da alma, mas a própria mente em ato conhecendo clara e distintamente, de sorte que a razão é o conatus intelectual quando o esforço de conhecer se explica exclusivamente pela potência da mente. Usar a razão é o esforço da mente para perseverar na existência compreendendo a si mesma, seu corpo e os corpos exteriores, esforço que se deduz apenas da necessidade interna ou da natureza da própria mente e que por isso é o primeiro e único fundamento da virtude (Espinosa 6, E IV, 20 c). A razão é, pois, a virtude ou potência da mente, ato de compreensão atual que tem seu fim em si mesmo.

Por seu turno, o desejo também é a própria essência do homem quando determinado a agir por uma afecção que nele se encontra. Passivo e servo, se a afecção que o determina é causada pela força de uma potência externa, o desejo pode tomar-se ativo se a afecção lhe for interna. Essa interioridade lhe é dada quando a razão lhe oferece o que desejar. Assim, a razão precisa do desejo para penetrar na vida afetiva - pois só um afeto mais forte e contrário pode destruir um outro afeto - e o desejo precisa da razão para tomar-se virtude da mente, igualando a potência afetiva e a potência intelectual, de sorte que a essência do homem possa ser definida como idêntica à sua potência, seja esta o desejo ou o conhecimento. Para retirar o desejo da passividade e servidão em que se encontra originariamente, a razão the oferece o exemplar naturae humanae, determinando-o internamente, ainda que a imaginação, num primeiro momento, experimente o exemplar como norma externa. A norma da natureza humana sendo a própria natureza humana como noção comum, o desejo encontra no interior de si mesmo a força para não sucumbir à Fortuna.

Compreendemos, então, porque o Livro IV define o apetite como fim: trata-se da causa eficiente desejante que recebe da razão os móveis internos para agir com virtude, mas porque está originariamente mergulhado na ser- 
vidão, experimenta-os, primeiro, como fins e somente depois os reconhece como sendo ele próprio ou causa eficiente determinada pela virtude da mente. Um dos mais belos momentos da geometria dos afetos, no Livro IV, surge quando, ainda no interior da paixão, ignorar é experimentado pela razão como tristeza e conhecer, como alegria. Ora, o Livro III demonstrou que as paixões nascidas do desejo e da alegria podem tornar-se ações quando nos tornamos causa adequada deles. É a alegria de conhecer que suscitará, internamente, o desejo de conhecer, fazendo com que a mente deseje aquilo que ela é: virtude de conhecer. Experimentado afetivamente como alegria, portanto, como paixão forte que se torna ação, o conhecimento, afeto mais forte, sintetiza razão, desejo e virtude.

Abstract: This article intends to analyse Book IV of Ethics and to present Spinoza's concept of freedom and human servitude in a different way from traditional criticism in his philosophy: as he distinguishes two points of view - "being a part" and "to have a part" -, one can say that there is no contradiction between the absolutely necessary nature ("fatalism") and the deduction of wise's freedom.

Key-words: finitude - freedom - servitude.

\section{Notas}

(1) Uma idéia inadequada é uma imagem que a mente forma sobre seu corpo e sobre os corpos exteriores por meio das afecções corporais de que ela é a consciência. Isto significa que a mente conhece seu corpo através da ação de outros corpos sobre ele e conhece estes últimos pelas ações de seu corpo sobre eles; portanto, não conhece a essência dele e deles, nem a sua própria. Uma idéia adequada é um conceito que a mente, a partir de si mesma, forma de seu corpo e dos corpos exteriores, bem como de si mesma conhecendo a causa ou razão das essências e existências dele, deles e dela. Na idéia inadequada, a mente imagina o real a partir da experiência imediata; na idéia adequada, conhece o real a partir da gênese necessária das essências das coisas singulares e de suas relaçães necessárias. As definições dos dois tipos de idéias se completam com as da causa inadequada e adequada. A causa inadequada é a causa parcial, isto é, aquela que não oferece a razão total de seus efeitos, pois não é causa integral deles (donde o vínculo necessário entre idéia inadequada, causa inadequada e passividade) ; a causa adequada é aquela cujos efeitos podem ser plenamente conhecidos através dela porque ela os causa integralmente a partir de sua própria natureza (donde o vínculo necessário entre idéia adequada, causa adequada e atividade) . Conatus é o esforço que uma coisa singular realiza para permanecer na existência (no corpo, são os movimentos ou afecções internos e externos; na mente, o esforço para conhecer; os dois esforços são inseparáveis e constituem a essência atual de um ser humano). O conatus se realiza inadequada e adequadamente.

(2) Assim, por exemplo, lemos em Sêneca: "Vês a que má e nociva (malam et noxiam) servidão estará submetido aquele que é possuído alternadamente pelos prazeres e dores, esses senhores (dominia) incertíssimos e tirânicos (incertissima impo-tentissimaque) . É preciso, pois, dirigir-se para a liberdade e só se chega a ela pela indiferença à fortuna (fortunae neglegentia)". (Sêneca 22, parte $V$, p. 55) . A terminologia é muito próxima da de Espinosa e, à primeira vista, as idéias também.

(3) Essa distinção, que São Tomás sistematiza, partindo da Ética a Nicômaco, na Summa Theologica, II, II, 93, 1, é mantida por Bacon, Boyle, Suarez, Newton e Locke. Para este último cf. Tully 27. 
(4) Cf. Emout/Meillet 16, verbete Ius, p. 329.

(5) Para o problema da abstração cf. Teixeira 25.

(6) Se Espinosa tem como alvo direto os platônicos e neoplatônicos judaicos e cristãos, sua crítica também alcança os aristotélicos, aos quais se aplica a afirmação de que "crêem que a Natureza falhou ou pecou, deixou imperfeita a coisa", pois se, platonicamente, a Natureza é imperfeição, aristotelicamente é mais fraca do que a arte, precisa desta como suplemento que corrija a imitação natural, o artefato/artifício preenchendo a carência natural e podendo fazê-lo porque arte e Natureza são finalizadas.

(7) No Moreh Nebukin, Maimônides escreve: "Entre o conhecimento que o artífice possui de sua obra e o de qualquer outro sobre ela, há muita diferença. Se a obra foi executada de acordo com a ciência do artífice, este a realiza conforme ao seu saber; em contrapartida, para quem contemple a obra e a entenda à sua maneira, o conhecimento é posterior à obra, enquanto para o artífice, a ciência permite a obra, é anterior a ela (...) Ao contrário, aquele que contempla e observa a máquina, a cada movimento dela consegue obter um conhecimento novo e os conhecimentos prosseguem à medida que avança na observação, até adquirir conhecimento exato de todo o mecanismo (...) Alcançamos apenas o que nos vem da contemplação dos seres, por isso nosso conhecimento não alcança o futuro e o infinito (...) Com relação a Deus - Exaltado seja! - não ocorre o mesmo. Seu conhecimento não se deriva das coisas, pois elas dependem de Sua ciência, que é anterior e as dispôs tais como são, seja como entes separados da matéria, seja como indivíduos dotados de matéria (...) Tentarmos conhecer como é isto, equivaleria a pretender que somos Ele e nossa percepção, a Sua (...) Se o soubéssemos, estaríamos de posse de um intelecto capaz disso, o que é impossível, pois só Deus - Exaltado seja! - o possui (...) Essas questões graves e elevadas excluem toda demonstração, tanto para nós como para os fillósofos, salvo no que está demonstrado pela Torah." (Maimônides 15, pp. 435-36)

(8) As proposiçães do Livro I que estão sendo mencionadas são: prop. 15 "Tudo o que existe, existe em Deus e sem Deus nada pode existir nem ser concebido" (Deus é a causa da existência de todas as coisas e também da inteligibilidade de todas elas); prop. 16 "Da necessidade da natureza divina devem resultar coisas infinitas em número infinito de modos, isto é, tudo o que pode cair sob um intelecto infinito" (a Natureza existe em Deus como efeito e conseqüiência da essên- cia divina e é plenamente inteligível); os corolários desta proposição enunciam: corol. 1 "Daqui resulta que Deus é causa eficiente de todas as coisas que podem cair sob um intelecto infinito"; corol. 2 "Resulta, em segundo lugar, que Deus é causa por si e não por acidente"; corol. 3 "Resulta, em terceiro lugar, que Deus é absolutamente causa primeira". A proposição 17 afirma: "Deus age somente segundo as leis de sua natureza sem ser constrangido por ninguém" (a potência ou causalidade divina é livre porque resulta da espontaneidade da essência divina); os corolários desta proposição enunciam: corol. 1 "Não existe causa alguma, extrínseca ou intrínseca a Deus que o incite a agir, além da perfeição de sua própria natureza", e corol. 2 "Só Deus é causa livre. Com efeito, só Deus existe pela única necessidade de sua natureza e age somente pela necessidade de sua natureza, pelo que somente ele é causa livre". A proposição 18: "Deus é causa imanente de todas as coisas e não causa transitiva" (Deus é causa eficiente, ativa de todos os seres sem que eles se separem dele; isto é, os efeitos são reais e diferentes de Deus, mas não são seres separados dele e sim expressões singulares dele) . Na análise destas quatro proposições, estarei acompanhando os comentários de Martial Guéroult (11, v. I) sobre o Liviro I.

(9) Potentia é a força interna de atividade ou ação; é espontânea e, por isso mesmo, necessária. Potestas é um poder para fazer ou não fazer, agir ou não agir, estando ligada à vontade como poder para agir e não agir, sendo, por isso, contingente. Facultas é uma capacidade para alguma coisa, podendo ou não ser exercida, pois, como a palavra indica, é facultativa; vincula-se à vontade como faculdade para querer ou não querer, fazer ou não fazer. Espinosa, como veremos, rejeita a potestas (em Deus) e a facultas (no homem) porque critica a imagem da vontade como poderio e como um poder ser ou não ser, fazer ou não fazer, agir ou não agir. Deus age pela necessidade de sua essência. O homem age pela necessidade da potência divina e pela necessidade de sua própria potência. Assim, potentia absorve os outros termos e elimina a contingência da vontade (no caso da Natureza, elimina a realidade metafísica da Fortuna, pois a Fortuna é imagem; no caso do homem, elimina a imagem do livre-arbítrio como definição da liberdade pela contingência da escolha).

(10) Na tradição teológico-metafísica, Deus possui como atributos: intelecto onisciente, vontade onipotente, bondade, justiça, misericórdia, etemidade, infinitude. Espinosa recusa o intelecto e a vontade como atributos divinos: são modos infinitos e finitos de um atributo, o pensamento; portanto, não existem o intelecto 
criador nem a vontade criadora, pois, como modos, são criaturas, efeitos. Deus é constituído (e não, composto) por infinitos atributos infinitos em seu gênero, dos quais conhecemos dois: a extensão e o pensamento. Eternidade e infinitude não são atributos, mas propriedades da essência divina. Justiça, misericórdia, bondade etc. não são atributos nem propriedades de Deus, mas imagens antropomórficas da divindade. Ao modalizar o intelecto e a vontade, Espinosa completa o percurso de despersonalização e despersonificação de Deus. No pensamento teológico-político, a personalidade e personificação de Deus eram fundamentais para garantir: 1. a origem legítima do poder do governante, que o recebia da vontade de Deus; 2. a semelhança entre o governante e Deus, ambos dotados de intelecto e vontade; 3. a posição de Deus como sujeito de direito e, portanto, como tendo dominium ou a propriedade de sua obra, o mundo, doando ao homem esse direito, fazendo-o ser proprietário também. Como mostra Tully (27), em Locke, Deus, além de senhor, é fabricador e proprietário da obra e por isso o homem também será proprietário legítimo de suas obras, do produto de seu trabalho. Sem um deus pessoal, não há como legitimar a propriedade privada.

(11) A proposição 35 do Livro I enuncia: "Tudo o que concebemos estar no poder (potentia) de Deus existe necessariamente" (portanto, tudo o que existe é necessário) .

(12) A imagem do homem como império num império, criticada no prefácio do Livro III, é decorrente da atribuição ao homem e à Natureza de finalidades, vontades, contingência da ação etc. A Natureza é imaginada como império (potestas) ou como poder (imperium) de Deus e o homem, como um poder voluntário (potestas e/ou facultas) e arbitrário que rivaliza com o poder da Natureza, desordenando e perturbando a ordem natural.

(13) A proposição 2 do Livro III enuncia: "Nem o corpo pode determinar a mente a pensar, nem a mente pode determinar o corpo ao movimento e ao repouso ou a qualquer outra coisa, se outra coisa houver". Essa proposição inaugura a ruptura espinosana face à tradição para a qual a ação é um movimento da alma sobre o corpo ou deste sobre ela, e a paixão é o receber a ação do outro termo, de sorte que a paixão da alma sería causada pelo corpo e a paixão do corpo, pela alma. Na filosofia espinosana, a relação mente-corpo não sendo de causalidade recíproca, uma vez que modos de atributos diferentes não podem manter relações causais, é uma relação de simultaneidade dos acontecimentos, de sorte que quando o corpo é passivo (por ação dos corpos externos) a alma também o é, e quando o corpo é ativo, a alma também o é; e vice-versa. Corpo e alma são passivos juntos e ativos juntos. Ora, a tradição fazia a liberdade depender justamente do poder da alma sobre o corpo e por isso, na demonstração dessa proposição, Espinosa afirma o que será reafirmado no Prefácio do Livro IV: "A experiência faz ver, portanto, tão claramente quanto a razão, que os homens se julgam livres (isto é, não determinados) apenas porque são conscientes das ações e ignorantes das causas pelas quais são determinados; e, além disso, as decisões da mente nada mais são que os próprios apetites e, por conseguinte, variam conforme as disposições variáveis do corpo". No Livro III, a ignorância quanto às causas da ação (isto é, que em tudo, seja na paixão seja na ação, somos determinados por causas determinadas) leva a considerar a vontade como uma faculdade da alma e sede da liberdade - tem-se a imagem da liberdade, contestada pela própria experiência e pela razão. No Livro IV, a ignorância quanto às causas da ação leva à posição do apetite como causa final e, portanto, novamente, à imagem da vontade que age tendo em vista fins externos racionais.

(14) Cf. Ficino 8, 1, XIII, 3. Para Ficino, é o parentesco entre a inteligência humana e a divina que permite ao homem (através da arte) aspirar a produzir uma nova realidade e tornar-se plenamente divino ou artífice completo. Deus é geômetra, arquiteto, artesão e sua obra de arte é a natureza. O conhecimento das coisas é conhecimento de suas proporções e harmonias necessárias e, portanto, a geometria é uma ciência teórica que produz seus objetos e permite a criação de novas realidades, se a ela forem dados os instrumentos e a matéria para isto. A limitação do homem concerne, pois, à disponibilidade de matéria e instrumental para a criação, mas, emprincípio, a arte humana é ilimitada, como a divina.

(15) Cf. Galileu 9. Veja-se ainda Clavelin 2; Koyré 14. Sobre o mesmo tema em Hobbes, veja-se Shapin/Schaffer 23; Sacksteder 20. Cf. ainda Mondolfo 17.

(16) Máquina é um instrumento cuja causa é externa e cujo movimento é nela impresso por uma força externa. Autômato é um ser que possui em si mesmo a causa de sua ação ou movimento, é uma força espontânea autodeterminada.

(17) Cair sob um intelecto infinito significa ser plenamente inteligível e plenamente inteligido. A expressão espinosana indica, de um lado, o conhecimento que Deus, através do modo infinito imediato do pensamento, possui da totalidade do que é produzido por sua essência-potência e, de outro lado, o acesso do homem, enquanto modo finito do pensamento, ao conhecimento pleno da realidade. No 
Livro V, Espinosa demonstrará que conhecemos exatamente como Deus conhece, mesmo que não conheçamos tudo quanto ele conhece. Ao dessubstancializar o homem, Espinosa garante-lhe o pleno acesso intelectual ao infinito do qual é parte e no qual pode tomar parte ativamente.

(18) - O intelecto infinito de Deus possui apenas idéias adequadas (isto é, aquelas cuja causa e razão total são conhecidas em sua necessidade interna) . O homem possui idéias inadequadas (as imagens ou idéias imaginativas) quando sua mente conhece idéias que envolvem o conhecimento que o intelecto infinito possui, mas não exprimem tal conhecimento; são as idéias que nossa mente tem enquanto Deus é causa simultânea de todas as coisas singulares da Natureza Naturada. Mas o homem é capaz de idéias adequadas quando a idéia exprime a essência atual e eterna de seu corpo, de sua mente e dos corpos exteriores ou da Natureza inteira enquanto Deus está constituindo a essência singular de nossa mente; são as idéias que nossa mente é quando pensa. No primeiro caso, o conhecimento que temos não coincide com o conhecimento que o infinito tem; no segundo caso, o conhecimento que somos coincide com o conhecimento que Deus é, pois trata-se de Deus modificado em uma essência singular e não apenas modificado enquanto o todo da Natureza Naturada.

(19) A proposição 24 do Livro I enuncia: "A essência das coisas produzidas por Deus não envolve a existência". Na demonstração lemos: "É evidente. Com efeito, aquilo cuja natureza (considerada em si) envolve a existência é causa de si (causa sui) e existe pela necessidade somente de sua natureza". Por seu turno, o corolário dirá: "Daqui se segue que Deus não só é a causa porque as coisas começam a existir, senão também de que perseverem na existência ou, em outras palavras (para me servir de um termo escolástico), Deus é causa de ser (causa essendi) das coisas. Com efeito, as coisas, quer existam, quer não existam, todas vezes que Ihes consideramos a respectiva essência reconhecemos que esta não envolve a existência nem a duração; por isso a essência delas não pode ser a causa nem de sua existência nem da sua duração, mas somente Deus, à natureza do qual pertence o existir, o poder ser". Deus é causa da essência e da existência das coisas e por isto estas últimas não possuem uma essência que, por si mesma, as ponha na existência.

(20) Cf. Espinosa 4, CM, I, 3; 5, II, parág. 52, 53; 7, KV, I, 6; 6, E I, 29; e 6, E I, 33, esc. Em todos estes textos, Espinosa define o necessário e o impossível com relação à essência e à existência ou causa; define o contingente e o possível como idéias imaginativas relativas à essência e à causa e os coloca como defeitos do conhecimento (nos Cogitata Metaphysica, no De Emendatione e na Korte Verhandeling) e como carência de conhecimento verdadeiro (na Ethica) . Não há contingência objetiva nem possibilidade objetiva e as imagens da contingência e da possibilidade se formam, seja porque desconhecemos a contradição interna que impossibilita uma essência, seja porque desconhecemos as causas necessárias da existência de uma essência que sabemos não ser internamente contraditória. No Livro IV, a definição 3 enuncia: "Chamo contingentes às coisas singulares enquanto, considerando somente a sua essência, nada encontramos que ponha ou exclua necessariamente sua existência"; e a definição 4: "Chamo possíveis às mesmas coisas singulares enquanto, atendendo nós às causas pelas quais devem ser produzidas, ignoramos se elas são ou não determinadas a produzi-las". Espinosa observa: "No escólio da proposição 33 da parte I não fiz nenhuma distinção entre possível e contingente, porque aí não havia necessidade de os distinguir com cuidado". De fato, no Livro I, possível e contingente se equivalem, uma vez que são ambos inexistentes e seu caráter subjetivo os torna irrelevantes para a dedução da natureza divina. No Livro IV, porém, a distinção (o contingente se refere à existência da essência; o possível se refere à causa) é indispensável porque o primeiro movimento do conhecimento certo do bom e do mau dependerá dela.

(21) O movimento dedutivo, nos livros II, III, IV e V, segue o mesmo padrão: Espinosa sempre inicia na imaginação-inadequação-pars partialis, passa para a razão-adequação-pars communis e chega à intelecção-adequação-pars singularis. A dedução opera sempre em dois registros: no da ordem comum da Natureza e no da ordem necessária da Natureza e nesta, novamente em dois registros, no da noção comum e no da essência singular. Desta maneira, em cada livro, o finito aparece como imaginação-inadequação-passividade e como razão-adequaçãoatividade. Em cada um deles, Espinosa demonstra o caráter necessário da imaginação e da reflexão, demonstrando que, na relação entre o interior e o exterior (ou entre cada individualidade corpo-alma e mundo), a pars, incomensuravelmente menos potente do que o todo, pode dispor de uma força interna própria capaz ou de transformar o extrínseco/contingente em intrínseco/necessário (passando da diminuição ao aumento da perfeição ou realidade), ou de afastar o contrário pelo comum (passando da privação à afirmação). Em cada um deles, Espinosa demonstra que a passagem da idéia inadequada à adequada e da causa inadequada à adequada é uma aptidão própria ao finito e que, assim como o intelecto finito pode conhecer exatamente como o intelecto infinito (ao conhecer 
a razão ou causa total de uma essência singular), assim também pode ser causa adequada (ao envolver o modo finito como causa total do que ocorre dentro e fora de si em virtude de sua força interna). Inadequação: porque somos partes de uma Substância cuja potência é incomensurável à nossa e que nos produz produzindo simultaneamente todo o real, podemos dar às partes uma autonomia abstrata porque as conhecemos de maneira parcial. Passividade e submissão à contingência da fortuna (ou ordem comum da Natureza) estão inscritas na pars partialis como sua marca necessária. Adequação: porque somos modos de uma Substância que se autoproduz produzindo a diferenciação infinita de suas modificações, somos capazes do verdadeiro e da liberdade, isto é, de reflexão e autonomia no interior da ordem necessária da Natureza.

(22) A idéia inadequada envolve privação. A paixão envolve negação. Tanto a privação quanto a negação estão articuladas à idéia de pars, quando a parte está separada do todo. Desde a carta 21, a Blyenbergh, os termos privação e negação são criticados por Espinosa: a negação, negando que pertença a uma essência o que não pertence de fato e de direito à sua natureza, é flatus vocis; a privação, supondo que pertença à natureza de alguma coisa algo de que ela estaria privada, é uma falta, uma carência ou uma perda (o vidente que se torna cego). Se a negação é vazia, a privação é uma idéia inadequada, imagem abstrata sobre a essência singular, a partir de um padrão geral (gênero ou espécie). Na Ética, porém, Espinosa demonstra que as coisas particulares (e não as essências singulares) são aquelas que não podem ser conhecidas nem ser concebidas sem as outras, pertencendo ao encadeamento causal tanto da ordem comum quanto da ordem necessária da Natureza. Que querem dizer: não podem e sem as outras? Este não e este sem colocam privação e negação num contexto diverso do da carta 21, pois agora não estamos diante de essências singulares, mas diante de coisas particulares, de partes. Agora, estamos diante da afimação de que: omnis determinatio negatio. Dois sentidos estão presentes neste adágio: por um lado, é a diferenciação entre essências singulares e, por outro lado, é a foma de coexistência de coisas particulares. Como diferenciador, a negação traça o contorno que distingue uma singularidade de outra enquanto essência, mas sendo contorno e não ato de produção de uma singularidade, isto é, sendo apenas limite e separação, a negação não diz respeito à atividade que põe uma essência, mas apenas ao que dela está excluído. Como forma da coexistência das coisas particulares, a negação se refere apenas à impossibilidade de compreender cada uma delas sem se referir à totalidade das coisas. Em outras palavras, na passividade a coisa particular não é causa total de seus efeitos, mas estes são causados por forças exteriores e, portanto, a paixão de uma coisa particular é incompreensível sem a referência às coisas exteriores que agem sobre ela e a determinam; a origem do que se passa na coisa particular passiva está fora dela, no que não é ela. A privação é intrínseca à idéia inadequada e à causa inadequada; a negação está referida a um sistema de relaçães entre partes finitas isoladas ou partes abstratas e à sua coexistência na ordem comm da Natureza e, no caso das essências singulares, ao limite externo que distingue uma essência de outra, sem qualquer referência, porém, à natureza da própria essência. Com isto, a negação está na origem da privação, pois aquilo que falta à parte decorre de ter sido ela tomada sem as demais. Privação e negação definem o conatus como causa inadequada ou parcial e a finitude como passividade afetiva e imaginativa. Privação (na imagem) e negação (na paixão) abrem caminho para compreendermos o que Espinosa chama de contrários, a contrariedade sendo nuclear na servidão. o que é uma idéia contrária ao nosso ser, idéia que podemos ter mas que não pode nos exprimir? o que é uma idéia que exclui a existência atual de nosso corpo e de nossa alma? É uma paixão. E uma paixão triste, da qual somos, portanto, apenas a causa parcial e da qual as causas externas mais fortes são a outra causa parcial. Como a paixão é volúvel e mutável, pois está na dependência das circunstâncias de tempo e lugar, da disposição atual do corpo próprio e dos corpos circundantes, da imagem que a alma possua de seu corpo e das imagens que possua dos corpos exteriores, a contingência permeia toda a vida afetiva, de sorte que as paixões de alegria podem tornar-se tristes e os desejos que acompanham a alegria podem tornar-se desejos que acompanham a tristeza. Essa contingência afetiva - fortunae potestas - faz com que qualquer coisa possa ser por acidente causa de alegria ou tristeza, desejada ou indesejada. É nesse campo da contrariedade das forças internas e externas que transcorre a servidão ou de viribus affectibus.

Assim, se articularmos os conceitos de pars, idéia inadequada, causa inadequada e força dos contrários desembocaremos no axioma que abre o Livro IV: não há coisa alguma na Natureza que não haja outra mais forte e poderosa do que ela; dada uma coisa qualquer, é dada outra mais forte que pode destruí-la. E a primeira proposição da Parte IV nos desencoraja de qualquer interpretação intelectualista para o problema da servidão: "nada do que uma idéia falsa tem de positivo é suprimido pela presença do verdadeiro enquanto verdadeiro", isto é, o verdadeiro enquanto verdadeiro não é mais forte e poderoso do que o que há de positivo no falso. Afimação que mutatis mutandis ressurge na proposição 14 do Livro IV: "o verdadeiro conhecimento do bem e do mal, enquanto verdadeiro, não 
pode refrear nenhum afeto, a não ser quando é considerado um afeto". Essa proposição remete a duas outras que são a chave da servidão e da liberdade racional: na proposição 5 do Liviro IV lemos que "a força e crescimento de qualquer paixão e sua perseverança na existência não são definidas pela potência pela qual nós nos esforçamos para perseverar na existência, mas pela potência de uma causa externa em comparação com a nossa" e na proposição 7 do Livro IV, "um afeto não pode ser refreado nem suprimido senão por um afeto contrário mais forte do que o afeto a refrear".

Como se articulam pars e contrarium? Na proposição 4 do Livro IV lemos: "é impossível que o homem não seja uma parte da Natureza e que não possa sofrer outras mudanças senão aquelas que podem ser compreendidas apenas pela sua natureza e de que é causa adequada", e no corolário: "daqui resulta que o homem está sempre necessariamente sujeito às paixões, que ele segue a ordem comum da Natureza e lhe obedece e que a ela se adapta tanto quanto o exige a natureza das coisas". Ser parte é ser necessariamente passivo e estar sob o poderio de forças externas mais potentes, contrárias à nossa natureza. Assim, não são as essências singulares nem as coisas particulares que são contrárias umas às outras, mas a força de suas potências. Desta maneira, podemos compreender a definição da servidão tanto quanto a de bom e mau. A servidão é definida como impotência (para moderar e refrear os afetos) que nos lança sob fortunae potestate. Não padecemos porque somos uma parte da Natureza, mas enquanto somos uma parte que não poole ser concebida por si mesma, isto é, a passividade e a servidão determinam a heteronomia da coisa singular enquanto parte que é determinada pelo que não é ela. Por isso a força de uma paixão aumenta quanto maior a força das causas exteriores.

Mal e servidão estão internamente articulados, referindo-se à pars partialis da Natureza que, isolada das demais e separada de si mesma pela força das causas exteriores, é heterônoma, está sob o senhorio da fortuna e submetida à desagregação de impulsos contrários. Pars partialis e pars contraria definem a condição da parte na servidão. Pars communis e pars conveniens definirão a situação da parte na liberdade racional. Pars totalis e pars imanens definirão a situação da parte na liberdade intelectual.

\section{Bibliografia}

1. Benvéniste, E. Le Vocabulaire des Institutions Indo-Européennes. Paris, Minuit, 1969, vol. 2.

2. Clavelin, M. La Philosophie Naturelle de Gali lée. Paris, Amand Colin, 1968.

3. Deleuze, G. Spinoza et le Problème de l'Expression. Paris, Minuit, 1968.

4. Espinosa. Cogitata Metaphisica. In: Spinosa Opera. Ed. Gebhardt. Heidelberg, 1925, vol. 1.

5. - Tratactus de Intellectus Emendatione, ed. cit., vol. 2.

6. . Ethica more geometrico demonstrata, ed. cit, vol. 3 .

7. . Korte Verhandeling, ed. cit., vol. 1.

8. Ficino, Marsiglio. Theologia Platonica. Paris, Les Belles Lettres, 1964.

9. Galileu, G. Duas Novas Ciências. São Paulo, Instituto Italiano di Cultu$\mathrm{ra}, \mathrm{s} / \mathrm{d}$.

10. Giannotti, J. A. O Ardil do Trabalho. In: Trabalho e Reflexão. São Paulo, Brasiliense, 1983.

11. Guéroult, M. Spinoza. Paris, Aubier, 1967, vol. 1.

12. Heidegger, M. La Question de la Technique. In: Essais et Conférences. Paris, Gallimard, 1954.

13. Hobbes, T. Leviathan. Harmondsworth, Penguin Books, 1968.

14. Koyré, A. Estudos Galilaicos. Lisboa, Don Quixote, 1986.

15. Maimônides. Guia de Perplejos., Madri, Editora Nacional, 1983.

16. Meillet, A./Ernout, A. Dictionnaire Etymologique de la Langue Latine. Paris, Klincksieck, 1985. 
17. Mondolfo, R. Figuras y Ideas de la Filosofía del Renascimiento. Buenos Aires, Losada, 1954.

18. Nicholas, B. An Introduction to Roman Law. Oxford, Clarendon Press, 1982.

19. Rossi, P. Os Filósofos e as Máquinas. São Paulo, Companhia das Letras, 1989.

20. Sacksteder, W. Man the Artificer - Notes on Animals, Humans and Machines in Hobbes. In: Southern Journal of Philosophy, vol. XXII, n. 1, 1984.

21. Spinoza on the Part and Whole: the Worm's Eye View. In: Sahan, R./Biro, J.I. (org.), Spinoza: New Perspectives. Normam, University of Oklahoma Press, 1980.

22. Sêneca. De Vita Beata. Paris, Hachette, 1882.

23. Shapin, S/Schaffer, S. Leviathan and the Air-Pump-Hobbes, Boyle and the Experimental Life. Princeton, Princeton University Press, 1985.

24. Suarez. De Legibus ac Deo Legislatore. Oxford, Carnegie Endowment Edition, 1944.

25. Teixeira, L. A Doutrina dos Modos de Percepção e o Problema da Abstração na Filosofia de Espinosa. São Paulo, Boletim da Faculdade de Filosofia, Ciências e Letras da Universidade de Såo Paulo, 1956.

26. Tuck, R. Natural Rights Theories - Their Origins and Development. Cambridge, Cambridge University Press, 1979.

27. Tully, J. A Discourse on Property - John Locke and his Adversaires. Cambridge, Cambridge University Press, 1982.

28. Vemant, J.-P. Le Travail et la Pensée Technique. In: Mythe et Pensée chez les Grecs. Paris, Maspéro, 1969. 